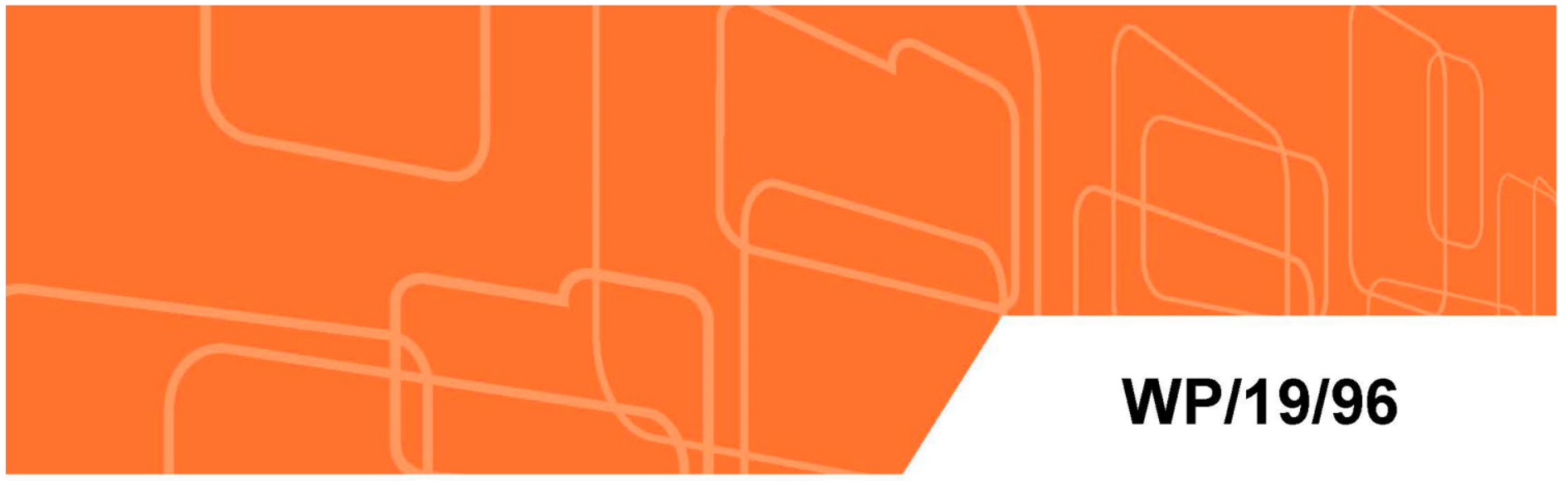

IMF Working Paper

\title{
The Value Added Tax and Growth: Design Matters
}

by Santiago Acosta-Ormaechea and Atsuyoshi Morozumi

IMF Working Papers describe research in progress by the author(s) and are published to elicit comments and to encourage debate. The views expressed in IMF Working Papers are those of the author(s) and do not necessarily represent the views of the IMF, its Executive Board, or IMF management. 


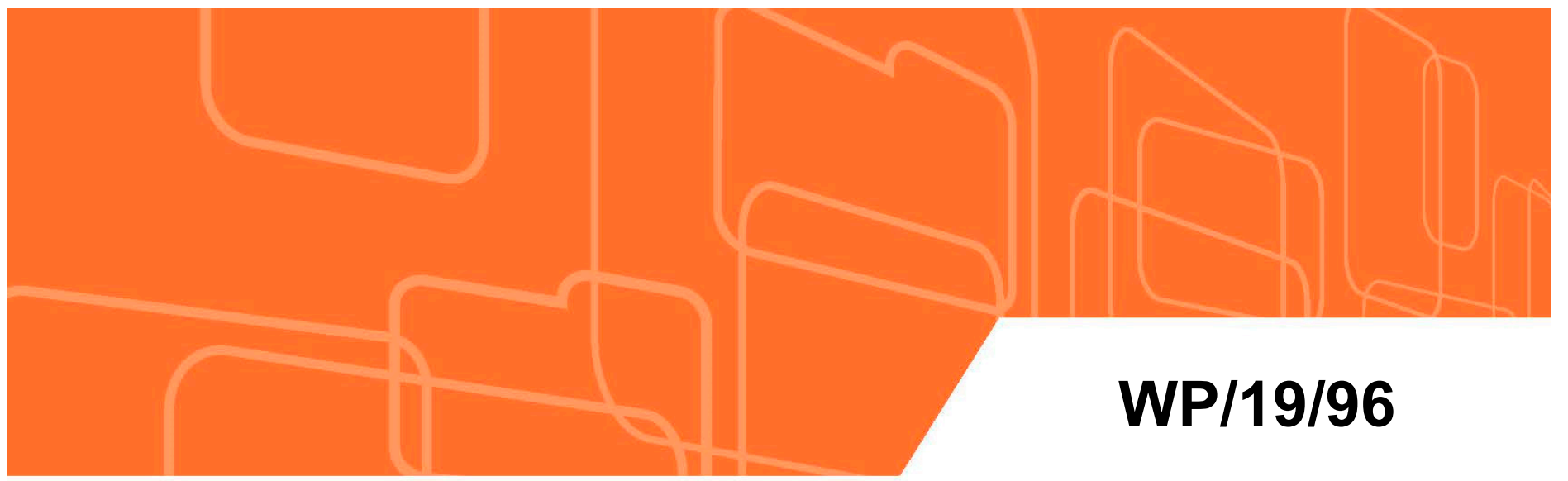

\section{IMF Working Paper}

\section{The Value Added Tax and Growth: Design Matters}

by Santiago Acosta-Ormaechea and Atsuyoshi Morozumi

IMF Working Papers describe research in progress by the author(s) and are published to elicit comments and to encourage debate. The views expressed in IMF Working Papers are those of the author(s) and do not necessarily represent the views of the IMF, its Executive Board, or IMF management. 


\title{
IMF Working Paper
}

Institute for Capacity Development

\section{The Value Added Tax and Growth: Design Matters \\ Prepared by Santiago Acosta-Ormaechea and Atsuyoshi Morozumi*}

Authorized for distribution by Charles Kramer

April 2019

\begin{abstract}
IMF Working Papers describe research in progress by the author(s) and are published to elicit comments and to encourage debate. The views expressed in IMF Working Papers are those of the author(s) and do not necessarily represent the views of the IMF, its Executive Board, or IMF management.
\end{abstract}

\begin{abstract}
Does the design of a tax matter for growth? Assembling a novel dataset for 30 OECD countries over the 1970-2016 period, this paper examines whether the value added tax (VAT) may have different effects on long-run growth depending on whether it is raised through the standard rate or through C-efficiency (a measure of the departure of the VAT from a perfectly enforced tax levied at a single rate on all consumption). Our key findings are twofold. First, for a given total tax revenue, a rise in the VAT, financed by a fall in income taxes, promotes growth only when the VAT is raised through C-efficiency. Second, for a given VAT revenue, a rise in Cefficiency, offset by a fall in the standard rate, also promotes growth. The implication is thus that in OECD countries broadening the VAT base through fewer reduced rates and exemptions is more conducive to higher long-run growth than a rise in the standard rate.
\end{abstract}

JEL Classification Numbers: E62, H20, O47

Keywords: VAT; Economic growth; Standard rate; C-efficiency; Base broadening

Author's E-Mail Address: SAcostOrmaechea@imf.org, Atsuyoshi.Morozumi@nottingham.ac.uk

\footnotetext{
* We thank Shun-ichiro Bessho, Andy Berg, Michael Bleaney, Valerie Cerra, Valerio Crispolti, Hamid Davoodi, Michael Keen, Arbind Modi, Mick Thackeray, Junji Ueda, and Francisco Veiga for their comments. The conventional disclaimer applies. Atsuyoshi Morozumi: School of Economics, University of Nottingham, University Park, Nottingham NG7 2RD, UK; and Ministry of Finance, Japan.
} 


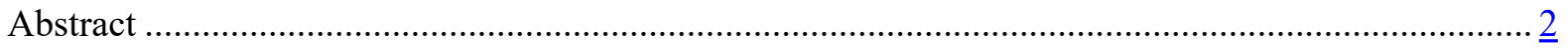

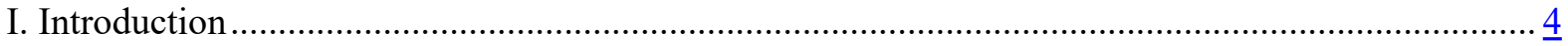

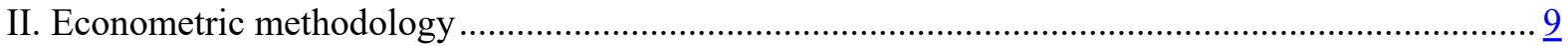

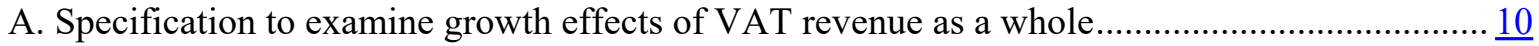

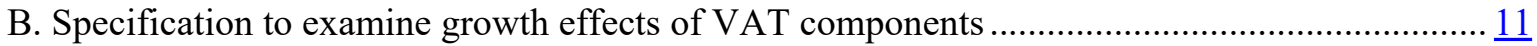

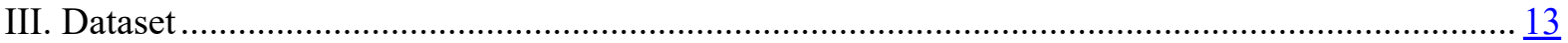

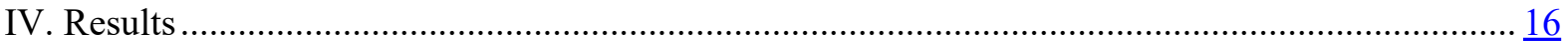

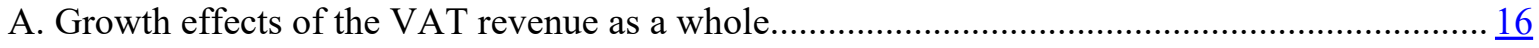

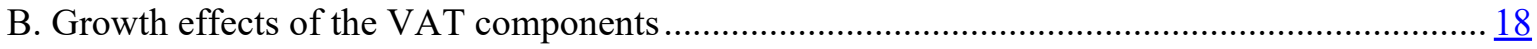

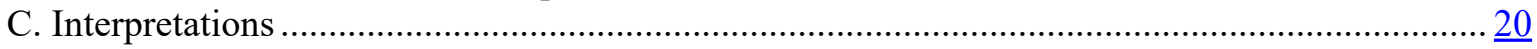

Why is a rise in C-efficiency particularly growth promoting? ............................................. $\underline{20}$

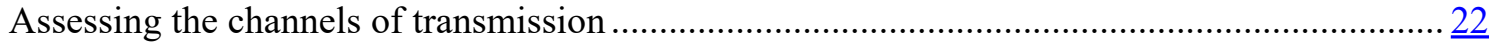

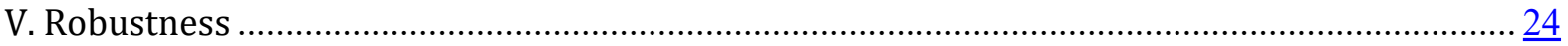

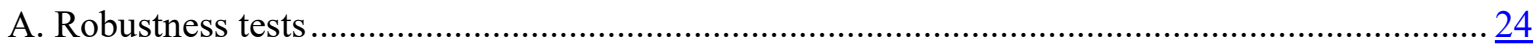

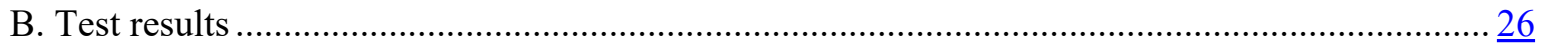

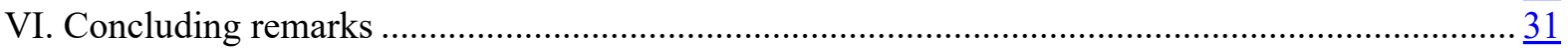

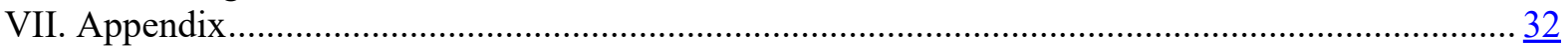

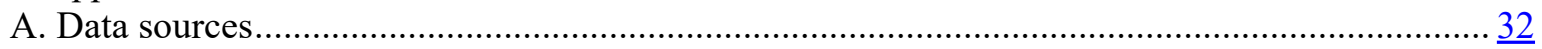

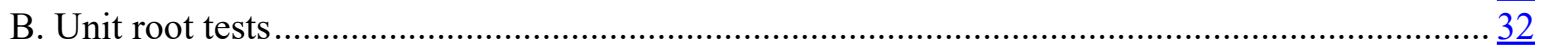

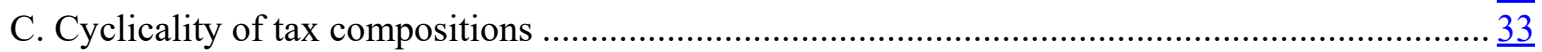

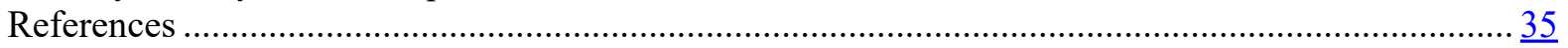

Tables

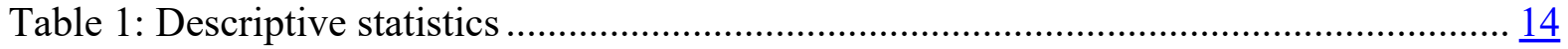

Table 2: Long-run growth effects of revenue-neutral increase in VAT …......................... 17

Table 3: Long-run growth effects of VAT components ............................................... $\frac{19}{23}$

Table 4: Allowing for different channels of transmission .......................................... $\frac{23}{28}$

Table 5: Robustness (1): omitting the post-crisis period and adding initial GDP per capita.. $\underline{28}$

Table 6: Robustness (2): using ARDL with 2 lags and omitting contemporaneous relation . $\underline{30}$

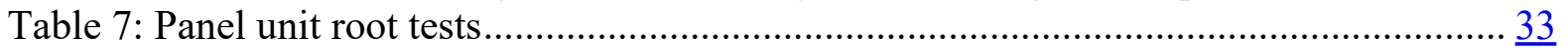

\section{Figures}

Figure 1: Evolution of the VAT and its components in OECD countries since 1993 ........... 15

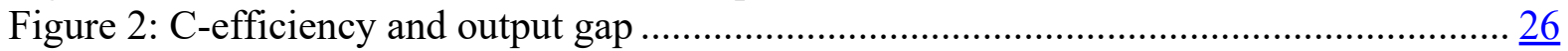

Figure 3: Correlation between tax shares and output gap........................................... 34 


\section{INTRODUCTION}

Does the growth effect of a tax depend on whether it is raised through a rate increase or through a base broadening? The previous empirical literature on taxation and growth has largely been silent on this question. However, this could be unsatisfactory from a policy perspective, because deciding to raise (or reduce) certain tax revenue necessarily requires the specification of the form in which this is achieved. For instance, the previous literature stresses that the composition of taxes matters for growth, often suggesting that income taxes are significantly more distortionary than consumption taxes (e.g., Arnold et al., 2011 and Acosta-Ormaechea et al., 2018). However, little is investigated about whether a rise in (lessdistorting) consumption taxes offset by the (more-distorting) income taxes foster growth regardless of how these tax revenues are modified. In this paper, we bring the design of a tax collection to the forefront of the analysis. Specifically, focusing on the value-added tax (VAT), a type of consumption tax which has become particularly popular worldwide over the last few decades, we examine if the form in which VAT revenue is raised matters for longrun growth. ${ }^{1}$

To consider the role of the design of the VAT, we require a well-defined method for decomposing it. To this end, we follow Keen (2013), and decompose VAT revenue, $V$ (as a share of total tax revenue, $T$ ) as $V / T=\tau e c$, where $\tau$ is the VAT standard rate, the rate applied to the largest portion of taxed consumption; $e(=V /(\tau C))$ is C-efficiency, the ratio of VAT revenue to the product of the VAT standard rate and final consumption, $C$ (excluding VAT revenue collection); and $c(=C / T)$ is the ratio of final consumption to total tax revenue. Among these components, C-efficiency measures the departure of the VAT from a perfectly enforced tax levied at a single rate on all consumption, and takes a value lower than one, to the extent that reduced rates and exemptions apply to some goods, and/or taxpayers' compliance is limited (Ebrill et al., 2001 and IMF, 2011). ${ }^{2}$ Keen (2013) and Ueda (2017)

\footnotetext{
${ }^{1}$ As of November 1, 2018, 168 countries and territories worldwide have adopted the VAT, including all the OECD countries with the only exception of the US (which has adopted, instead, a sales tax). (See OECD, 2018, for details). As seen in Table 1 below, on average, 20 percent of total taxation is collected through the VAT in the OECD.

${ }^{2}$ The VAT is a tax levied on the sale of goods (and services) by registered businesses not only to private consumers but also to other businesses and, importantly, businesses offset the VAT they have been charged on their purchases (inputs) against the liability on their sales (output). Therefore, if a uniform VAT rate is applied to all goods, and if taxes are enforced perfectly, the VAT revenue equals the uniform rate of the (tax-exclusive) value of the sales made to final consumers, i.e., C-efficiency takes the value of one.
} 
suggest that in advanced economies trends in C-efficiency are primarily explained by changes in policy choices of rate differentiations and exemptions, rather than changes in compliance. ${ }^{3}$ Therefore, (at least) for those advanced economies, base broadening measures such as removing reduced rates and exemptions appear to be key driving forces of $\mathrm{C}$ efficiency increases in the long run. ${ }^{4}$

How might the long-run growth effects of the VAT in advanced economies differ depending on whether it is raised through the standard rate or C-efficiency? One plausible conjecture is that raising VAT revenue through a rise in C-efficiency is more growth promoting than doing so through a rise in the standard rate. Fundamentally, this conjecture is based on the argument put forward by Crawford et al. (2010) and Cnossen (2010), who indicate that VAT exemptions distort firms' input choices and thus create an element of production taxation. This, in turn, follows from the fact that exemptions mean that no tax is charged on sales, but VAT charged on inputs is not refunded or credited. Then, given that various sectors in the economy, including healthcare, education, and financial sectors, are often exempted, distortions created within the production process can have significant adverse effects on the economy, which, in turn, could lead to lower growth in the long run through different channels (as elaborated below). Thus, the elimination of exemptions, corresponding to a base broadening and thus higher C-efficiency, could be particularly growth promoting. Moreover, the elimination of rate differentiations lowers administration costs caused by having multiple rates (e.g., Ebrill et al., 2001) and also decreases distortions in consumers' spending decisions (e.g., Mirrlees et al., 2011). Reducing those distortions, reflected in a rise in C-efficiency, may also have positive macroeconomic effects. ${ }^{5}$ On the

\footnotetext{
${ }^{3}$ Specifically, Keen (2013) and Ueda (2017) decompose C-efficiency further into 'gaps' related to aspects of policy choices of rate differentiation and exemption (policy gap) and taxpayers' compliance (compliance gap) and show that the former gap is a key driver of C-efficiency. In particular, Ueda (2017), using data between 2000-2014 covering a panel of EU member countries and Japan, show that cumulative changes in C-efficiency are largely driven by cumulative changes in policy gaps. Since our own analysis below requires (at least) 20 years of continuous annual observations, the data restriction prohibits us to decompose of C-efficiency into those gaps.

${ }^{4}$ Importantly, however, a rise in C-efficiency does not always correspond to a broadening of the VAT base, which can lead to efficiency gains. For example, as Keen (2013) points out, there are other reasons why Cefficiency can increase, including the introduction of exemptions for intermediate goods and/or denying VAT refunds to exporters (the standard procedure is to refund them the VAT paid on their inputs). Due to data limitations, however, we are unable to assess further all possible determinants of C-efficiency increases.

${ }^{5}$ Admittedly, since there is no clear theory about how reduction in relative price distortions may help promote growth, this argument is rather speculative. What has been more established in the literature so far is that
} 
contrary, increasing the VAT through the standard rate instead forgoes the aforementioned efficiency gains, which would be achieved through a base broadening. ${ }^{6}$

To test formally the relevance of VAT design on long-run growth, we assemble a novel dataset covering 30 OECD countries during the 1970-2016 period. To proceed, we examine the growth effects of the standard rate and C-efficiency in two different contexts. First, we examine how for a given level of total revenue, a rise in the VAT, offset by a fall in income taxes, might have different growth effects depending on whether VAT revenue is raised through $\mathrm{C}$-efficiency or through the standard rate. Second, we consider how for a given level of VAT revenue, a rise in C-efficiency, financed by a fall in the standard rate, affects growth. Notice that the latter exercise helps us compare directly the growth effects of C-efficiency and the standard rate. We use the Pooled Mean Group (PMG) estimation method of Pesaran et al. (1999), which enables us to estimate the long-run growth impact of a tax policy change, while allowing for heterogeneity in the short-run dynamics across countries. $^{7}$

Our results indicate that an increase in the VAT through a rise in C-efficiency is more conducive to higher long-run growth than through a rise in the VAT standard rate. First, a total revenue-neutral rise in the VAT, offset by a fall in income taxes, increases growth if the VAT is raised through C-efficiency, but not if it is raised through the VAT standard rate. Second, a VAT revenue neutral rise in C-efficiency, offset by a fall in the standard rate, also promotes growth, suggesting that the former is more growth promoting than the latter. Thus, the implication is that in OECD countries increasing VAT revenue through base broadening with fewer reduced rates and exemptions is more growth friendly than doing so through standard rate increases. We show that our results largely stand to various robustness checks, including: 1) the exclusion of the Global Financial Crisis (GFC) period and its aftermath

moving towards a uniform rate and reducing relative price distortions can lead to sizable gains in consumers' welfare (e.g., Mirrlees et al., 2011).

${ }^{6}$ This paper does not explore in detail the growth effect of the VAT through the consumption ratio $(c)$. This is primarily because this component is of less policy relevance, i.e., less direct control of policymakers, than the standard rate and $\mathrm{C}$-efficiency as a proxy for VAT base measures. In principle, however, a larger ratio reflects a larger share of the economy outside formal tax registries. Thus, if the degree of informality in the economy is measured by "revenue not reported to, and not discovered by, the tax authorities produced in underground activities (Tanzi, 1999, F344)", a rise in this ratio may correspond to a lager informal economy.

7 To allow further for possible heterogeneity in the long-run growth effects, we also consider the Mean Group (MG) method of Pesaran and Smith (1995). However, when testing the equality of long-run coefficients across countries, the Hausman test predominantly supports the use of the PMG method in our estimations (i.e., it cannot reject the equality of the coefficients). 
(2008-16), when the growth pattern for OECD countries appears to be systematically different from that observed in previous years; 2) the inclusion of lagged real GDP per capita as an independent variable, addressing possible convergence effects; 3) the adoption of different short-run dynamics between taxation and growth, using different lag structures in the regression model; and 4) the consideration of possible endogeneity biases caused by reverse causality, i.e., from growth to tax variables.

This paper is related to the empirical works that assess the growth effects of different tax revenue categories. The relation is closer to those papers that take account of the government budget constraint (GBC) as a "closed system", whereby a change in one fiscal component must be balanced by an equal and opposite change in other component(s) to meet the GBC. ${ }^{8}$ For instance, using a panel of 21 OECD countries over 34 years, Arnold et al. (2011) find that in the context of (total) revenue-neutral tax reallocations, a rise in consumption taxes, offset by a fall in income taxes, promotes growth. Although Xing (2012) suggests that results might not be fully robust, Acosta-Ormaechea et al. (2018) confirm that consumption taxes are indeed more growth friendly than income taxes even in a broader sample of 70 countries over 40 years. ${ }^{9}$ Relatedly, assessing 15 OECD countries during more than 30 years but focusing instead on different tax rate measures (instead of tax revenue shares), Gemmell et al. (2014) show that consumption taxation is less harmful for growth than either personal or corporate taxation. However, these papers do not examine the role of the VAT per se, and, more importantly, whether the design of how taxes are collected affects growth, as we do here. ${ }^{10}$

Regarding the empirical literature that focuses on the VAT, an investigation on how this tax, a major source of tax revenue in many countries, affects macroeconomic aggregates, is surprisingly limited. Among this strand of the literature, Alm and El-Ganainy (2013), for

\footnotetext{
${ }^{8}$ See Kneller et al. (1999) for a seminal discussion on the relevance of GBC in growth regressions. For an extensive review of the literature on taxation and growth see Kneller and Misch (2011).

${ }^{9}$ Some important differences in results remain between Arnold et al. (2011) and Acosta-Ormaechea et al. (2018). Specifically, while the former find that corporate income taxes are the most harmful taxes for growth, the latter show that personal income taxes and social security contributions have a more detrimental growth impact than corporate income taxes.

${ }^{10}$ Consumption taxes nest other components (than the VAT) such as sales tax and excises. As explained, the VAT is a tax levied on the sale of goods and services by registered businesses not only to private consumers but also to other businesses, and thus is different, for example, from a sales tax, which only taxes sales to final consumers.
} 
instance, show in a panel of 15 EU countries over the 1961-2005 period that increases in the VAT rate could lead to both short- and long-run reductions in aggregate consumption.

However, EC (2011) argue that the long-run effects of the VAT and its components - such as the standard rate and C-efficiency — on either aggregate consumption or GDP growth are negligible in 40 countries using a sample period of more than 50 years. ${ }^{11}$ To clarify, a key difference between this paper and ours is that we estimate the growth effects of the different VAT components by explicitly incorporating the GBC (i.e., specifying their compensating elements within the budget constraint). This allows us to better discern the relative strength of each VAT component on growth, thereby strengthening the policy implications. ${ }^{12}$ More recently, Riera-Crichton et al. (2016) and Dabla-Norris and Lima (2018) investigate how VAT rates (and also the VAT base in the case of Dabla-Norris and Lima, 2018) affect the size of fiscal multipliers, whereas our focus in this paper is on the long-run growth effects of different VAT components.

Last, various papers also examine how C-efficiency evolves both in the short run and long run. Regarding the short-run fluctuation, Sancak et al. (2010), using a broad sample of advanced and developing countries, report that $\mathrm{C}$-efficiency is pro-cyclical. They find that shifts in consumption patterns toward goods and services with reduced VAT rates and higher tax evasion could explain the observed reductions in C-efficiency during economic contractions. Further, Ueda (2017), using a panel of EU countries and Japan from 2000 to 2014, explores the effects of business cycles on C-efficiency by decomposing the latter into compliance and policy gaps. Turning to an analysis of the structural determinants of Cefficiency changes, Tanzi and Davoodi (2000), using a sample of 83 countries, show that countries with higher corruption tend to have lower C-efficiency. Further, Aizenman and Jinjarak (2009) find, using a panel of 44 countries, that lower durability of political regimes reduces C-efficiency. ${ }^{13}$ While those studies shed light on the short- and long-run determinants

\footnotetext{
${ }^{11}$ In their paper, C-efficiency is referred to as VAT revenue ratio.

${ }^{12}$ As explained, we consider the effects of the VAT standard rate and C-efficiency, compensated by a change in income taxes (for a given total tax revenue) and by other VAT components (for a given VAT revenue). Meanwhile, since EC (2011) do not specify which fiscal element is adjusted when each VAT component changes, their estimated coefficients do not provide a policy-relevant interpretation. Further, their specification does not allow for a direct comparison of the growth effects of the different VAT components.

${ }^{13}$ Further, De Mello (2009) point out other structural factors associated with C-efficiency, such as the efficiency of tax administration and the country's governance indicators.
} 
of C-efficiency, our focus is instead on the long-run consequences of a change in Cefficiency (alongside a change in the VAT standard rate) on economic growth.

The rest of the paper is organized as follows. Section II explains our empirical methodology. Section III describes the dataset. Section IV presents and interprets results, and Section V conducts robustness checks. Section VI concludes.

\section{ECONOMETRIC METHODOLOGY}

Following recent empirical works on fiscal policy and growth (e.g., Arnold et al, 2011 and Gemmell et al., 2011, 2014, 2016), we use the pooled mean group (PMG) methodology of Pesaran et al. (1999). This method allows us to estimate the long-run growth effects of the VAT in a cross-country setting, while allowing independent dynamics for each country. In the PMG method, the long-run relationship between the relevant variables and growth is constrained to be equal across countries. In the alternative mean group (MG) method of Pesaran and Smith (1995), separate autoregressive distributed lag (ARDL) models are estimated for each country, and the average of each parameter across all countries is then computed. However, if homogeneity of the long-run response is not rejected, the PMG estimator is preferred due to its higher efficiency relative to the MG estimator. ${ }^{14}$

Our baseline estimated equation is:

$$
\begin{aligned}
g_{i, t}=\boldsymbol{f}_{i, t}^{\prime} \delta_{0 i} & +\boldsymbol{f}_{i, t-1}^{\prime} \delta_{1 i}+\sum_{j=1}^{n} \delta_{0 i, j}^{Z} z_{i, j, t}+\sum_{j=1}^{n} \delta_{1 i, j}^{Z} z_{i, j, t-1}+\lambda_{i} g_{i, t-1}+\zeta_{i} \text { crisis }_{i, t} \\
& +\epsilon_{i, t}, \quad(1)
\end{aligned}
$$

where $g_{i, t}$ is the growth rate of annual real GDP per capita in country $i$ in year $t . \boldsymbol{f}_{i, t}^{\prime}$ is a vector of tax variables (clarified below); $z_{i, j, t}$ contains control variables (i.e., investment rates and employment growth). The choice of these control variables is based on Gemmell et al. (2011). The equation takes an ARDL structure, where both dependent and independent variables are included in the right-hand side with a lag of order 1. (A specification with longer lags is considered as part of the robustness checks.) As indicated by Gemmell et al.

\footnotetext{
${ }^{14}$ For all the models estimated below, we confirm that the Hausman test cannot reject the equality of long-run responses, supporting the use of the PMG method.
} 
(2011), this specification, when re-parameterized in an error-correction form, provides a flexible framework to estimate growth effects, in that it accommodates for the possibility that some fiscal variables have a long-run growth effect, while others may only have a short-run growth impact (i.e., only a level effect on output). Last, crisis $_{i, t}$ is a dummy variable that takes a value one for years after 2008 (inclusive) and zero otherwise. This is to account for the systematically stagnant growth pattern observed in high-income countries after the Global Financial Crisis of 2007-09 (GFC). ${ }^{15}$

\section{A. Specification to examine growth effects of VAT revenue as a whole}

The aim of this paper is to consider whether it matters for growth how the VAT is raised. To start, however, we consider the growth effects of the VAT without clarifying how it is raised. Taking into account the government's budget constraint, we consider the effect of the VAT in the context of a tax reallocation from income taxes (for a given level of total tax revenue). In this case, the vector of tax variables in Eq. (1) takes the form of:

$$
\boldsymbol{f}_{i, t}^{\prime} \delta_{0 i}=\delta_{0 i}^{T_{-} t a x} t_{-} t a x_{i, t}+\sum_{j=1}^{m} \delta_{0 i, j}^{S} s_{i, j, t}
$$

where $t_{-} \operatorname{tax}_{i, t}$ is the ratio of total tax revenue to GDP and $s_{i, j, t}$ is the share of tax component $j$ in total tax revenue, which comprises $m$ different tax types. Since $\sum_{j=1}^{m} s_{i, j, t}=1$ by construction, however, we omit one tax component to avoid perfect multicollinearity. To be specific, assume that there are three tax shares $(m=3)$ : VAT $\left(s_{i, V, t}\right)$, income taxes $\left(s_{i, I, t}\right)$, and other taxes $\left(s_{i, O, t}\right)$. If we omit the income tax share in Eq. (2), $s_{i, I, t}$, we have:

$$
\boldsymbol{f}_{i, t^{\prime}}^{\prime} \delta_{0 i}=\delta_{0 i}^{T_{-} t a x} t_{-} \operatorname{tax}_{i, t}+\left(\boldsymbol{\delta}_{\mathbf{0} i, \boldsymbol{V}}^{\boldsymbol{S}}-\boldsymbol{\delta}_{\mathbf{0 i , I}}^{\boldsymbol{S}}\right) s_{i, V, t}+\left(\delta_{0 i, O}^{S}-\delta_{0 i, I}^{S}\right) s_{i, O, t}+\delta_{0 i, I}^{S}
$$

A coefficient on the VAT share, $\boldsymbol{\delta}_{\mathbf{0} i, \boldsymbol{V}}^{\boldsymbol{S}}-\boldsymbol{\delta}_{\mathbf{0} i, \boldsymbol{I}}^{\boldsymbol{S}}$, then measures the growth effect of a revenueneutral increase in the VAT offset by income taxes. $\boldsymbol{f}_{i, t-1}^{\prime} \delta_{1 i}$ in Eq. (1) is defined likewise. ${ }^{16}$

\footnotetext{
${ }^{15}$ For instance, the average GDP per capita growth rate over 1990-2007 in our sample of 30 OECD countries is 2.78 percent, while over 2010-2016 is 1.56 percent. One theoretical explanation for the apparent structural change in high-income countries' growth is the secular stagnation hypothesis of Summers (2014).

${ }^{16} \boldsymbol{f}_{i, t-1}^{\prime} \delta_{1 i}=\delta_{1 i}^{T_{1} t a x} t_{-} \operatorname{tax}_{i, t-1}+\left(\delta_{1 i, V}^{S}-\delta_{1 i, I}^{S}\right) s_{i, V, t-1}+\left(\delta_{1 i, O}^{S}-\delta_{1 i, I}^{S}\right) s_{i, O, t-1}+\delta_{1 i, I}^{S}$.
} 
The long-run growth effects of a rise in the VAT offset by income taxes can be estimated after re-parameterizing Eq. (1) in an error correction form:

$$
\begin{aligned}
& \Delta g_{i, t}=\phi_{i}\left(g_{i, t-1}-\theta_{i}^{T-t a x} t_{t a x}{ }_{i, t-1}-\left(\boldsymbol{\theta}_{i, \boldsymbol{V}}^{S}-\boldsymbol{\theta}_{i, I}^{S}\right) \boldsymbol{s}_{\boldsymbol{i}, \boldsymbol{V}, \boldsymbol{t}-\mathbf{1}}-\left(\theta_{i, O}^{S}-\theta_{i, I}^{S}\right) s_{i, O, t-1}-\sum_{j=1}^{n} \theta_{i, j}^{Z} Z_{i, j, t-1}\right) \\
& +\delta_{0 i}^{T-t a x} \Delta t_{t a x}+\left(\delta_{0 i, V}^{S}-\delta_{0 i, I}^{S}\right) \Delta \mathrm{s}_{i, V, t}+\left(\delta_{0 i, O}^{S}-\delta_{0 i, I}^{S}\right) \Delta \mathrm{s}_{i, O, t}+\sum_{j=1}^{n} \delta_{0 i, j}^{Z} \Delta \mathrm{z}_{i, j, t} \\
& +\zeta_{i} \operatorname{crisis}_{i, t}+\delta_{0 i, I}^{S}+\delta_{1 i, I}^{S}+\epsilon_{i, t},
\end{aligned}
$$

where $\phi_{i}=-\left(1-\lambda_{i}\right)$ represents the error-correction speed of adjustment. A key long-run coefficient is the one on the VAT share, $\boldsymbol{s}_{\boldsymbol{i}, \boldsymbol{V}, \boldsymbol{t}-\mathbf{1}}: \boldsymbol{\theta}_{\boldsymbol{i}, \boldsymbol{V}}^{\boldsymbol{S}}-\boldsymbol{\theta}_{\boldsymbol{i}, \boldsymbol{I}}^{\boldsymbol{S}}$, where $\theta_{i, V}^{S}=\left(\delta_{0 i, V}^{S}+\right.$ $\left.\delta_{1 i, V}^{S}\right) /\left(1-\lambda_{i}\right)$ and $\theta_{i, I}^{S}=\left(\delta_{0 i, I}^{S}+\delta_{1 i, I}^{S}\right) /\left(1-\lambda_{i}\right) \cdot{ }^{17}$ If this coefficient is positive, it means that an increase in VAT revenue, financed by a fall in income taxes, is associated with higher long-run growth. Subsequently, the terms in first-differences (denoted by $\Delta$ ) capture the short-run dynamics towards the long-run equilibrium.

\section{B. Specification to examine growth effects of VAT components}

To examine if the design of the VAT revenue collection matters for long-run growth, we modify Eq. (3) by using the aforementioned decomposition of VAT revenue share, $s_{i, V, t}\left(=V_{i, t} / T_{i, t}\right)=\tau_{i, t} e_{i, t} c_{i, t}$, where $\tau_{i, t}$ is the VAT standard rate; $e_{i, t}=V_{i, t} /\left(\tau_{i, t} C_{i, t}\right)$ is Cefficiency and $c_{i, t}=C_{i, t} / T_{i, t}$ is the ratio of final consumption to total tax revenue. Eq. (3) becomes:

$$
\begin{gathered}
\boldsymbol{f}_{i, t}^{\prime} \delta_{0 i}=\delta_{0 i}^{T_{-} t a x} t_{-} \operatorname{tax}_{i, t}+\left(\boldsymbol{\delta}_{\mathbf{0 i , V}}^{\boldsymbol{S}}-\boldsymbol{\delta}_{\mathbf{0 i , I}}^{\boldsymbol{S}}\right) s_{i, V, t}+\left(\delta_{0 i, O}^{S}-\delta_{0 i, I}^{S}\right) s_{i, O, t}+\boldsymbol{\delta}_{\mathbf{0} \boldsymbol{i}}^{\boldsymbol{E}} \boldsymbol{l n}(\boldsymbol{e})_{i, \boldsymbol{t}} \\
+\boldsymbol{\delta}_{\mathbf{0 i}}^{\boldsymbol{T}} \boldsymbol{l n}(\boldsymbol{\tau})_{\boldsymbol{i}, \boldsymbol{t}}+\boldsymbol{\delta}_{\mathbf{0} \boldsymbol{i}}^{\boldsymbol{C}} \boldsymbol{l n}(\boldsymbol{c})_{\boldsymbol{i}, \boldsymbol{t}}+\delta_{0 i, I}^{S}
\end{gathered}
$$

where the log of the three VAT components are added.

\footnotetext{
${ }^{17}$ The remaining long-run coefficients are $\theta_{i}^{T_{t} t a x}=\left(\delta_{0 i}^{T_{-} \operatorname{tax}}+\delta_{1 i}^{T_{1} t \operatorname{tax}}\right) /\left(1-\lambda_{i}\right), \theta_{i, O}^{S}=\left(\delta_{0 i, O}^{S}+\delta_{1 i, O}^{S}\right) /(1-$ $\left.\lambda_{i}\right)$, and $\theta_{i, j}^{Z}=\left(\delta_{0 i, j}^{Z}+\delta_{1 i, j}^{Z}\right) /\left(1-\lambda_{i}\right)$.
} 
Now, because Eq. (5) contains the VAT revenue share and all the three components simultaneously, one of them needs to be left out of the equation (otherwise, the coefficients cannot be interpreted). To do so, we make use of the fact that a linear approximation to the VAT revenue share, $s_{i, V, t}=\tau_{i, t} e_{i, t} c_{i, t}$, yields ${ }^{18}$

$$
s_{i, V, t} \cong a+b \ln (s)_{i, V, t}=a+b\left(\ln (\tau)_{i, t}+\ln (c)_{i, t}+\ln (e)_{i, t}\right) \text {. }
$$

Specifically, if we leave out the standard rate, $\ln (\tau)_{i, t}$ from Eq. (5), we obtain:

$$
\begin{aligned}
& \boldsymbol{f}_{i, t^{\prime}}^{\prime} \delta_{0 i}=\delta_{0 i}^{T_{-} t a x} t_{-} \operatorname{tax}_{i, t}+\left(\boldsymbol{\delta}_{\mathbf{0} i, \boldsymbol{V}}^{\boldsymbol{S}}+\boldsymbol{\delta}_{\mathbf{0} \boldsymbol{i}}^{\boldsymbol{T}} / \boldsymbol{b}-\boldsymbol{\delta}_{\mathbf{0} i, \boldsymbol{I}}^{\boldsymbol{S}}\right) s_{i, V, t}+\left(\delta_{0 i, O}^{S}-\delta_{0 i, I}^{S}\right) s_{i, O, t}+\left(\boldsymbol{\delta}_{\mathbf{0} i}^{\boldsymbol{E}}\right. \\
& \left.-\boldsymbol{\delta}_{0 i}^{T}\right) \ln (e)_{i, t}+\left(\delta_{0 i}^{C}-\delta_{0 i}^{T}\right) \ln (c)_{i, t}+\delta_{0 i, I}^{S}-\frac{a}{b} \delta_{0 i}^{T} .
\end{aligned}
$$

The coefficient on the VAT share, $s_{i, V, t}$ is $\delta_{0 i, V}^{S}+\delta_{0 i}^{T} / b-\delta_{0 i, I}^{S}$, instead of $\delta_{0 i, V}^{S}-\delta_{0 i, I}^{S}$ (cf. Eq. (3)), capturing the effect of a rise in the VAT (offset by a fall in income taxes) when it is driven only by an increase in the standard rate, the omitted VAT component. ${ }^{19}$ Notice also that the coefficient on C-efficiency, $\delta_{0 i}^{E}-\delta_{0 i}^{T}$ measures the growth impact of a rise in Cefficiency, offset by a fall in the standard rate, for a given level of VAT revenue.

Finally, using Eq. (7), Eq. (1) can be re-parameterized as:

$$
\begin{aligned}
& \Delta g_{i, t}=\phi_{i}\left(g_{i, t-1}-\theta_{i}^{T-t a x} t_{t a x}{ }_{i, t-1}-\left(\boldsymbol{\theta}_{\boldsymbol{i}, \boldsymbol{V}}^{\boldsymbol{S}}+\frac{\boldsymbol{\theta}_{\boldsymbol{i}}^{\boldsymbol{T}}}{\boldsymbol{b}}-\boldsymbol{\theta}_{\boldsymbol{i}, \boldsymbol{I}}^{\boldsymbol{S}}\right) \boldsymbol{s}_{\boldsymbol{i}, \boldsymbol{V}, \boldsymbol{t}-\mathbf{1}}-\left(\theta_{i, O}^{S}-\theta_{i, \boldsymbol{I}}^{S}\right) s_{i, O, t-1}-\left(\boldsymbol{\theta}_{\boldsymbol{i}}^{\boldsymbol{E}}-\boldsymbol{\theta}_{\boldsymbol{i}}^{\boldsymbol{T}}\right) \mathbf{l} \boldsymbol{n}(\boldsymbol{e})_{\boldsymbol{i}, \boldsymbol{t}-\mathbf{1}}\right. \\
& \left.-\left(\theta_{i}^{C}-\theta_{i}^{T}\right) \ln (c)_{i, t-1}-\sum_{j=1}^{n} \theta_{i, j}^{Z} z_{i, j, t-1}\right)+\delta_{0 i}^{T_{-} t a x} \Delta t_{t a x}+\left(\delta_{0 i, V}^{S}+\frac{\delta_{0 i}^{T}}{b}-\delta_{0 i, I}^{S}\right) \Delta \mathrm{s}_{i, V, t} \\
& +\left(\delta_{0 i, O}^{S}-\delta_{0 i, I}^{S}\right) \Delta \mathrm{s}_{i, O, t}+\left(\delta_{0 i}^{E}-\delta_{0 i}^{T}\right) \Delta \ln (e)_{i, t}+\left(\delta_{0 i}^{C}-\delta_{0 i}^{T}\right) \Delta \ln (c)_{i, t}+\sum_{j=1}^{n} \delta_{0 i, j}^{Z} \Delta \mathrm{z}_{i, j, t} \\
& +\zeta_{i} \operatorname{crisis}_{i, t}+\delta_{0 i, I}^{S}+\delta_{1 i, I}^{S}-\frac{a}{b}\left(\delta_{0 i}^{T}+\delta_{1 i}^{T}\right)+\epsilon_{i, t} .
\end{aligned}
$$

Here, the long-run coefficient on the VAT share, $\boldsymbol{\theta}_{\boldsymbol{i}, \boldsymbol{V}}^{\boldsymbol{S}}+\frac{\boldsymbol{\theta}_{\boldsymbol{i}}^{T}}{\boldsymbol{b}}-\boldsymbol{\theta}_{\boldsymbol{i}, \boldsymbol{I}}^{\boldsymbol{S}}$, where $\theta_{i}^{T}=\left(\delta_{0 i}^{T}+\right.$ $\left.\delta_{1 i}^{T}\right) /\left(1-\lambda_{i}\right)$, captures the long-run effect of an increase in VAT revenue, offset by a fall in

\footnotetext{
${ }^{18}$ A linear approximation of $\ln \left(s_{\mathrm{V}}\right)$ around the reference point $X$ (e.g., the mean of the VAT revenue share) gives $\ln \left(s_{V}\right) \cong \ln (X)+\frac{1}{X}\left(s_{\mathrm{V}}-X\right)$. Setting $a(\equiv X-\ln (X) X)$ and $b(\equiv X)$ gives Eq. (6).

${ }^{19}$ In Eq. (7), the coefficient on the log of the standard rate, $\delta_{0 i}^{T}$, is divided by the reference point of the linear approximation $b$. This converts the marginal effect of the log (of the standard rate) to the effect on the level.
} 
income taxes, when the rise in the VAT is solely taking place through an increase in the standard rate. ${ }^{20,21}$ Last, notice that in Eq. (8), the coefficient on the log of C-efficiency, $\boldsymbol{\theta}_{\boldsymbol{i}}^{\boldsymbol{E}}-$ $\boldsymbol{\theta}_{\boldsymbol{i}}^{\boldsymbol{T}}\left(=\left(\left(\delta_{0 i}^{E}+\delta_{1 i}^{E}\right)-\left(\delta_{0 i}^{T}+\delta_{1 i}^{T}\right)\right) /\left(1-\lambda_{i}\right)\right)$ captures the long-run effect of a rise in Cefficiency, offset by a fall in the standard rate, for a given level of VAT revenue. This coefficient allows us to compare the long-run growth effects of C-efficiency and the standard rate directly.

\section{Dataset}

To estimate Eqs. (4) and (8) above, we assemble a new dataset covering 30 OECD countries during the 1970-2016 period..$^{22}$ The data are annual, and only countries with at least 20 annual successive observations are included. ${ }^{23}$ Tax revenue data are at the general government level. Total taxes are the sum of consumption taxes (of which the VAT is a part); personal income taxes; corporate income taxes; property taxes; and social security contributions (which includes taxes on payroll and workforce). Because the data are annual, we adjust the VAT standard rate (which is set at different times within a year) by taking account of the month in which the rate is changed. Briefly, when the rate is changed in a given year, we take a weighted average of the rates prevalent before and after the change, using the information on the month in which it occurred. ${ }^{24}$ Then, once the (adjusted) standard rates are obtained, the C-efficiency measure can be calculated. But for this we also use data

\footnotetext{
${ }^{20}$ For completeness, $\theta_{i}^{C}=\left(\delta_{0 i}^{C}+\delta_{1 i}^{C}\right) /\left(1-\lambda_{i}\right)$. The remaining coefficients of Eq. (8) are as defined above. ${ }^{21}$ Likewise, if we omit C-efficiency from $\boldsymbol{f}_{i, t}^{\prime} \delta_{0 i}$ (and $\boldsymbol{f}_{i, t-1}^{\prime} \delta_{1 i}$ ), and re-parameterise the estimated equation accordingly, we can examine instead the long-run growth effect of a rise in the VAT driven only by a rise in Cefficiency.

${ }^{22}$ The countries included are Austria, Belgium, Chile, Czech Republic, Denmark, Estonia, Finland, France, Germany, Greece, Hungary, Iceland, Ireland, Israel, Italy, Japan, Korea, Latvia, Luxembourg, Netherlands, New Zealand, Norway, Poland, Portugal, Slovak Republic, Spain, Sweden, Switzerland, Turkey, and United Kingdom. Australia and Canada are not included (the former is excluded due to the limited observations, and the latter because the standard rates differ across provinces). The US does not have a VAT.

${ }^{23}$ The dataset is an unbalanced panel, reflecting differences in the timings of the VAT introduction. ${ }^{24}$ Specifically, we take the following procedure to adjust the VAT standard rate data. First, we collect data on: 1) the standard rate applicable in January 31 of each year $t$; and 2) the month in which any change happened (if the rate changed in a given year). Second, denoting the month of any rate change as $x$, for $x \neq 1$ we calculate the adjusted standard rate in a given year $\mathrm{t}$ as: $((\mathrm{x}-1) / 12) *$ rate $\_\mathrm{t}+((12-\mathrm{x}+1) / 12) *$ rate $\mathrm{t}+1$, where rate $\mathrm{t}+1$ is the new rate applicable in January 31 of year $t+1$. When $x=1$, namely that the new rate is applicable by January 31 of year $t$, we simply use rate $t+1$ as the standard rate for the whole year. For example, in Japan the VAT standard rate changed on 1 April 1997 from 3 to 5 percent. With $x=4$, the adjusted rate in 1997 equals 4.5 percent $(=(3 / 12) * 3+(9 / 12) * 5)$.
} 
on final consumption, which is as defined in the national account's statistics, but excluding VAT revenue. Appendix A presents data sources.

Table 1: Descriptive statistics

\begin{tabular}{lcccc}
\hline Variables & Mean & $\begin{array}{c}\text { Standard } \\
\text { deviation }\end{array}$ & Minimum & Maximum \\
\hline Growth rate of real GDP pc & 0.0226 & 0.0314 & -0.145 & 0.251 \\
Total taxes/GDP & 0.342 & 0.0742 & 0.108 & 0.494 \\
Consumption taxes/Total taxes & 0.336 & 0.0872 & 0.140 & 0.686 \\
Personal income taxes/Total taxes & 0.250 & 0.104 & 0.0496 & 0.574 \\
Corporate income taxes/Total taxes & 0.0864 & 0.0459 & 0.0167 & 0.332 \\
Property taxes/Total taxes & 0.0526 & 0.0317 & 0.00699 & 0.221 \\
Social security contribution/Total & 0.275 & 0.122 & 0 & 0.496 \\
taxes & & & & \\
& & & & \\
VAT/GDP & 0.0667 & 0.0176 & 0.0128 & 0.110 \\
VAT/Total taxes & 0.200 & 0.0581 & 0.0460 & 0.451 \\
Standard rate & 0.182 & 0.0489 & 0.0300 & 0.270 \\
C-efficiency & 0.563 & 0.131 & 0.323 & 1.244 \\
Consumption ratio & 2.106 & 0.687 & 1.060 & 6.468 \\
& & & & \\
Investment rate & 0.238 & 0.0456 & 0.0982 & 0.415 \\
Employment growth & 0.00895 & 0.0212 & -0.136 & 0.106 \\
\hline
\end{tabular}

Notes: For all the variables, the number of observations is 944 from 30 countries, corresponding to Table 3 below. Total taxes are calculated as the sum of 1) consumption taxes, 2) personal income taxes, 3) corporate income taxes, 4) property taxes, and 5) social security contributions (which includes taxes on payroll and workforce). VAT is included a part of consumption taxes. The VAT standard rate is the one adjusted by taking account of the information on the month in which the change in the rate took place in each country. Investment rates are defined as total investment (including both public and private) divided by GDP.

Table 1 presents descriptive statistics for the 30 OECD countries during the 19702016 period covered in the analyses shown below. The average annual growth rate of real GDP per capita is 2.3 percent. The size of total taxes, relative to GDP, is 34.2 percent, whereas the share of VAT within total taxes accounts for 20.0 percent. This is substantially smaller than the share of aggregate consumption taxes, 33.6 percent, which includes other types of consumption taxes such as excises. The share of income taxes, against which we consider the growth effect of the different components of the VAT, amounts to 34.0 percent of total taxes when personal and corporate income taxes are both combined. Regarding the components of the VAT, the standard tax rate shows an average of 18.2 percent, while that of C-efficiency is 56.3 percent. These figures, however, mask the presence of large heterogeneity across countries and over time. For instance, on average C-efficiency is highest 
in New Zealand (97.5 percent during the sample period), where the VAT base is quite broad..$^{25}$ The ratio of final consumption to total taxes, the last VAT component, is averaged at 211 percent. The table also contains statistics for the control variables used in the growth regressions (investment rate and employment growth).

Figure 1 shows the evolution of the average of the ratio of the VAT to total taxes (and also to GDP) and its components across the sample of OECD countries over the 1993-2016 period, when most of these countries already adopted the VAT. ${ }^{26}$ Since the early $1990 \mathrm{~s}$, there has been an upward trend in the share of the VAT in total taxes (and also in the ratio to GDP), reflecting its growing popularity as a major revenue source. Turning to the VAT components, the evolution of their averages shows quite diverse patterns. For instance, until the Global Financial Crisis (GFC) of 2007-09, the standard rate remained relatively unchanged, while C-efficiency gradually increased, and the consumption ratio decreased. ${ }^{27}$ The evolution of the different components after the crisis have somewhat changed, coinciding with a significant increase in the VAT standard rates in several OECD countries.

Figure 1: Evolution of the VAT and its components in OECD countries since 1993
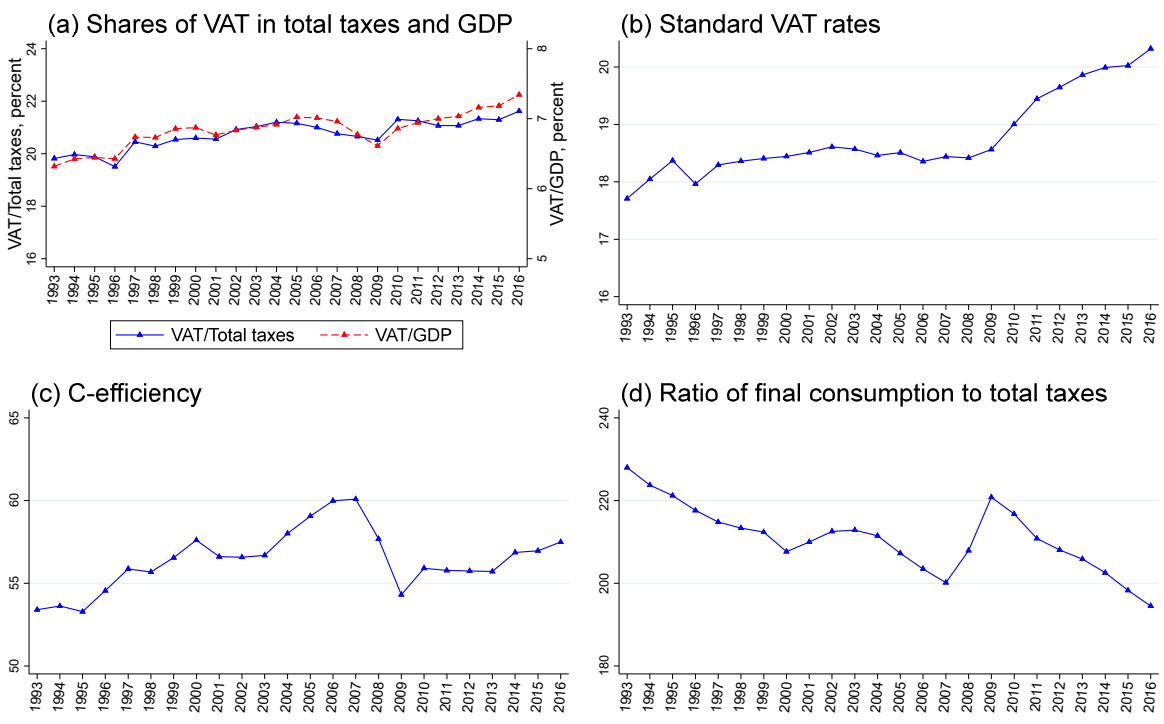

Notes: All figures are in percent. Average of 30 OECD countries. Source: Authors' calculations

\footnotetext{
${ }^{25}$ The highest value in the sample for C-efficiency belongs to Luxembourg (124.4 percent). This and other values above 100 percent reflect VAT collection which includes the effects of VAT-liable exports, such as cross border shopping by non-residents for fuel, reflecting lower VAT and excise rates than in neighboring countries, and "e-VAT" collection, which is VAT levied on electronic commerce within EU taxed at origin rather than at destination (see, e.g., Ueda, 2017, p. 34).

${ }^{26}$ The choice of 1993 as the starting year follows Keen (2013).

${ }^{27}$ These patterns are in line with those for high-income countries reported by Keen (2013).
} 
Before presenting the estimation results below, we check the time series properties of the variables. Specifically, Appendix B conducts two different panel unit root tests. To summarize the results briefly here, the Maddala and Wu (1999) test, which does not require a balanced panel, rejects the null of non-stationarity at a $1 \%$ significant level for all variables. Next, the Im et al. (2003) test, which also allows for an unbalanced panel and has been used extensively in the context of PMG estimated models, also shows that the null of nonstationarity is rejected at 1\% level for all variables (except for the log of VAT standard rate, which cannot be tested through this method). Given these results, our variables appear to be stationary. ${ }^{28}$

\section{RESUlts}

We first present results on the long-run growth effect of a reallocation of the VAT with income taxes, without exploring how VAT revenue is raised. Then, we examine how results are affected by specifying the form in which VAT revenue is raised. The tables below focus on the long-run coefficients on fiscal variables for brevity. Since the Hausman test cannot reject the PMG model (i.e., the cross-country homogeneity of the long-run coefficients is supported) in all the cases examined here, we only present results using this method. ${ }^{29}$ As noted above, only countries with at least 20 annual successive observations are used. However, the key results remain robust even when only countries with at least 30 successive observations are used instead (not shown for brevity). ${ }^{30}$

\section{A. Growth effects of the VAT revenue as a whole}

Table 2 presents the long-run growth effect of tax reallocations towards the VAT without specifying how VAT revenue is raised. To start, Column 1 shows the effects of a revenue-neutral increase in the VAT, where the financing component is the sum of all taxes apart from the VAT, denoted as "Rest". The long-run coefficient on the VAT is significantly positive, indicating that the VAT is growth promoting relative to all other remaining taxes

\footnotetext{
${ }^{28}$ Given our error-correction specification, we also assess whether the residuals from the estimations are stationary. Applying also the Maddala and Wu (1999) and Im et al. (2003) tests to the residuals of the estimated models in Table 3 for illustration, we can claim that these residuals are stationary, providing support to the presence of a long-run relation between the tax variables used in our model and growth (results are available from the authors upon request).

${ }^{29}$ Specifically, the p-value from the Hausman test takes a value larger than 0.05 for all the cases.

${ }^{30}$ In this case, the number of countries in the sample shrinks inevitably (to 16 countries for the case of Table 2 , to 14 for Table 3).
} 
combined. ${ }^{31}$ Next, Column 2 specifies the tax component used to finance the rise in the VAT as total income taxes, namely the sum of personal and corporate income taxes (as in Eq. (4)). There, the coefficient on the VAT share is positive and significant. Specifically, the coefficient of 0.085 indicates that a one percentage point increase in the share of the VAT in total taxes, offset by a fall in the share of (total) income taxes of the same size, is associated with a 0.085 percentage points increase in annual growth in the long run. ${ }^{32}$ Last, Columns 3 and 4 examine the growth effects of the VAT offset by either personal or corporate income taxes, respectively. While the coefficient on the VAT share is positive and significant in both columns, the fact that the coefficient is larger in Column 4 suggests that corporate income taxes could be more distortionary than personal income taxes.

Table 2: Long-run growth effects of revenue-neutral increase in VAT

\begin{tabular}{|c|c|c|c|c|}
\hline \multirow{2}{*}{$\begin{array}{l}\text { Estimation method } \\
\text { Financing taxes }\end{array}$} & \multicolumn{4}{|c|}{ PMG } \\
\hline & Rest & Total income & Personal income & Corporate income \\
\hline & $(1)$ & $(2)$ & $(3)$ & $(4)$ \\
\hline \multicolumn{5}{|c|}{ Dependent variable: real GDP per capita growth } \\
\hline Total taxes/GDP & $\begin{array}{c}-0.0858 * * * \\
(-3.95)\end{array}$ & $\begin{array}{c}-0.0872 * * * \\
(-3.98)\end{array}$ & $\begin{array}{c}-0.0848 * * * \\
(-3.76)\end{array}$ & $\begin{array}{c}-0.0773 * * * \\
(-3.57)\end{array}$ \\
\hline VAT/Total taxes & $\begin{array}{l}0.0768 * * * \\
(2.84)\end{array}$ & $\begin{array}{l}0.0848 * * * \\
(3.18)\end{array}$ & $\begin{array}{l}0.0731 * * * \\
(2.68)\end{array}$ & $\begin{array}{c}0.107 * * * \\
(2.98)\end{array}$ \\
\hline Other taxes/Total taxes & & $\begin{array}{c}-0.00655 \\
(-0.35)\end{array}$ & $\begin{array}{c}-0.0105 \\
(-0.52)\end{array}$ & $\begin{array}{r}0.0157 \\
(0.67)\end{array}$ \\
\hline Investment rate & $\begin{array}{l}0.0508^{* *} \\
(2.54)\end{array}$ & $\begin{array}{c}0.0480^{* *} \\
(2.46)\end{array}$ & $\begin{array}{c}0.0388^{*} \\
(1.90)\end{array}$ & $\begin{array}{l}0.0594^{* * * *} \\
(2.98)\end{array}$ \\
\hline Employment growth & $\begin{array}{c}0.444 * * * \\
(11.38)\end{array}$ & $\begin{array}{c}0.465 * * * \\
(12.43)\end{array}$ & $\begin{array}{c}0.463 * * * \\
(11.92)\end{array}$ & $\begin{array}{c}0.410 * * * \\
(10.14)\end{array}$ \\
\hline EC coefficient $(\phi)$ & $\begin{array}{c}-0.944 * * * \\
(-21.42)\end{array}$ & $\begin{array}{c}-0.964 * * * \\
(-20.09)\end{array}$ & $\begin{array}{c}-0.947 * * * \\
(-21.51)\end{array}$ & $\begin{array}{c}-0.940 * * * \\
(-21.34)\end{array}$ \\
\hline Crisis & $\begin{array}{c}-0.0172 * * * \\
(-8.47)\end{array}$ & $\begin{array}{c}-0.0168 * * * \\
(-7.77)\end{array}$ & $\begin{array}{c}-0.0171 * * * \\
(-8.42)\end{array}$ & $\begin{array}{c}-0.0158 * * * \\
(-7.79)\end{array}$ \\
\hline Countries & 30 & 30 & 30 & 30 \\
\hline Observations & 981 & 981 & 981 & 981 \\
\hline
\end{tabular}

Notes: PMG estimates (Hausman test supports PMG in all cases). The dependent variable is the annual growth rate of GDP per capita. The model is a variant of Eq. (4) and coefficients on all the tax variables, investment rate and employment growth refer to long-run elasticities. Total taxes are the sum of consumption taxes, personal income taxes, corporate income taxes, property taxes, and social security contributions (which includes taxes on payroll and workforce). VAT is a part of consumption taxes. In Column (1), financing taxes of "Rest" mean the sum of all taxes apart from the VAT. In Columns (2) to (4), Other taxes indicate "TotalVAT-Financing taxes". Crisis dummy takes one from 2008 to 2016 (inclusive) and zero for other years. Constants and coefficients on other variables are not shown for brevity. $t$ statistics in parentheses. ${ }^{*} p<0.10,{ }^{* *} p<0.05,{ }^{* * *} p<0.01$

\footnotetext{
${ }^{31}$ When considering the growth effect of aggregate consumption taxes (which contain not only the VAT but also other taxes such excises), we found that these are also more growth promoting than all other taxes combined. This is in line with previous literature (e.g., Arnold et al., 2011 and Acosta-Ormaechea et al., 2018). ${ }^{32}$ Given that in the OECD total taxes as share of GDP is 34 percent (Table 1), a one percentage point increase in the share of the VAT in total taxes corresponds to a rise in the VAT-to-GDP ratio of 0.34 percentage points. Alternatively, since the share of the VAT in total taxes is 20.0 percent in the OECD (Table 1), a one percentage point increase in the share of the VAT equals to a 5 percent increase in total VAT revenue.
} 
Turning to the remaining variables, the negative coefficient on total taxes shows that an increase in total taxes is growth reducing in the long run. However, since the financing element is not specified (e.g., a rise in total taxes can be offset by a rise in total spending and/or a fall in the budget deficit), the coefficient does not allow us to draw a specific interpretation. ${ }^{33}$ The long-run coefficients on investment rate and employment growth are both significantly positive. The error-correction speed of adjustment parameter $(\phi)$ is negative throughout and lower than one in absolute value, suggesting that convergence to the long-run equilibrium does take place. Last, the crisis dummy is always significant and negative, consistent with the systematically lower growth rates observed in OECD countries after the GFC.

\section{B. Growth effects of the VAT components}

Table 3 examines whether the design of VAT collection matters for long-run growth. For brevity, we focus on total income taxes (the sum of personal and corporate income taxes) as the tax category used to finance the VAT increase.

\footnotetext{
${ }^{33}$ It is possible to consider the growth effect of a rise in total taxes specifically, say, for 1) when it is offset by a rise in total spending, and 2) when offset by a fall in the deficit (see, for example, Morozumi and Veiga, 2016). Our focus here, however, is to assess the growth impact of a compositional change within total tax revenue.
} 
Table 3: Long-run growth effects of VAT components

\begin{tabular}{|c|c|c|c|c|}
\hline \multirow{3}{*}{$\begin{array}{l}\text { Estimation method } \\
\text { Financing taxes }\end{array}$} & \multicolumn{4}{|c|}{ PMG } \\
\hline & \multicolumn{4}{|c|}{ Total income } \\
\hline & $(1)$ & (2) & (3) & (4) \\
\hline \multicolumn{5}{|c|}{ Dependent variable: real GDP per capita growth } \\
\hline Total taxes/GDP & $\begin{array}{c}-0.0982^{* * *} \\
(-3.91)\end{array}$ & $\begin{array}{c}-0.0558 \\
(-1.40)\end{array}$ & $\begin{array}{c}-0.0447 \\
(-1.12)\end{array}$ & $\begin{array}{c}-0.0573^{*} \\
(-1.66)\end{array}$ \\
\hline VAT/Total taxes & $\begin{array}{c}0.0670^{* *} \\
(2.36)\end{array}$ & $\begin{array}{c}-0.0166 \\
(-0.53)\end{array}$ & $\begin{array}{c}0.187^{* * *} \\
(5.70)\end{array}$ & $\begin{array}{c}0.102^{*} \\
(1.68)\end{array}$ \\
\hline Other taxes/Total taxes & $\begin{array}{c}0.00727 \\
(0.36)\end{array}$ & $\begin{array}{c}0.0215 \\
(1.18)\end{array}$ & $\begin{array}{c}0.0354^{*} \\
(1.96)\end{array}$ & $\begin{array}{c}0.0162 \\
(0.86)\end{array}$ \\
\hline C-efficiency (log) & & $\begin{array}{c}0.0347^{* * *} \\
(4.86)\end{array}$ & & $\begin{array}{c}0.0153 \\
(1.53)\end{array}$ \\
\hline Standard rate $(\log )$ & & & $\begin{array}{c}-0.0277^{* * *} \\
(-4.87)\end{array}$ & $\begin{array}{c}-0.0175^{* *} \\
(-2.01)\end{array}$ \\
\hline Consumption ratio (log) & & $\begin{array}{c}0.0209^{*} \\
(1.79)\end{array}$ & $\begin{array}{c}-0.00823 \\
(-0.72)\end{array}$ & \\
\hline Investment rate & $\begin{array}{c}0.0634^{* * *} \\
(3.24)\end{array}$ & $\begin{array}{c}0.0436^{* *} \\
(2.04)\end{array}$ & $\begin{array}{c}0.0388^{*} \\
(1.79)\end{array}$ & $\begin{array}{c}0.0326 \\
(1.53)\end{array}$ \\
\hline Employment growth & $\begin{array}{c}0.457^{* * *} \\
(11.73)\end{array}$ & $\begin{array}{c}0.394^{* * *} \\
(10.23)\end{array}$ & $\begin{array}{c}0.389^{* * *} \\
(10.16)\end{array}$ & $\begin{array}{c}0.409^{* * *} \\
(10.97)\end{array}$ \\
\hline EC coefficient $(\phi)$ & $\begin{array}{c}-0.958^{* * *} \\
(-19.77)\end{array}$ & $\begin{array}{l}-0.911^{* * *} \\
(-17.57)\end{array}$ & $\begin{array}{c}-0.909^{* * *} \\
(-17.34)\end{array}$ & $\begin{array}{c}-0.924^{* * *} \\
(-17.41)\end{array}$ \\
\hline Crisis & $\begin{array}{c}-0.0159^{* * *} \\
(-7.64)\end{array}$ & $\begin{array}{c}-0.0133^{* * *} \\
(-6.08) \\
\end{array}$ & $\begin{array}{c}-0.0138^{* * *} \\
(-6.25) \\
\end{array}$ & $\begin{array}{c}-0.0136^{* * *} \\
(-6.03)\end{array}$ \\
\hline Countries & 30 & 30 & 30 & 30 \\
\hline Observations & 944 & 944 & 944 & 944 \\
\hline
\end{tabular}

Notes: The models in Columns 2 to 4 are a variant of Eq. (8). See notes to Table 1.

To start, since the number of observations is somewhat smaller than in Table 2 (due to the limited data availability of VAT standard rates), Column 1 replicates the estimation of the long-run growth effect of the VAT offset by a fall in (total) income taxes (cf. Column 2 in Table 2). The coefficient on the VAT share (0.067) is still significantly positive.

Column 2 adds the VAT components of ( $\log$ of) C-efficiency and the ratio of final consumption to total taxes, while omitting the standard rate (as in Eq. (8)). Notably, the coefficient on the VAT share is not significant anymore, indicating that when the VAT is raised only through a rise in the standard rate (omitted component), a rise in the VAT, financed by a fall in income taxes, does not promote growth. In contrast, in Column 3 where C-efficiency is omitted, the coefficient on the VAT share is positive and highly significant. This indicates that if the VAT is raised only through a rise in C-efficiency, the same tax reallocation leads to higher growth. Quantitatively, a one percentage point increase in the 
share of the VAT through C-efficiency increases an annual GDP per capita growth rate by 0.19 percentage points, 2.4 times larger than the effect when the form in which the VAT is raised is unspecified (see Column 1). Correspondingly, in Column 2 the coefficient on Cefficiency is positive and significant. This means that for a given level of VAT revenue a rise in C-efficiency, offset by a fall in the standard rate, also promotes growth. ${ }^{34}$ The indication is thus that C-efficiency is significantly more growth friendly than the standard rate. This result is consistent with the negative and significant coefficient on the standard rate in Column 3.

Last, Column 4, which omits the ratio of final consumption to total taxes (consumption ratio), shows that the coefficient on the VAT is positive and significant, albeit the level of significance is only at 10 percent. This indicates that a rise in the VAT through this component, offset by a fall in income taxes, also increases growth. Having acknowledged this result, however, since consumption relative to tax revenue is of less policy relevance (i.e., less direct control of policymakers) than either the standard rate or Cefficiency, we do not explore the growth effect through this component further. Besides, as seen below, the growth effect is far from robust, so that no clear implications can be drawn regarding this component. ${ }^{35}$

\section{Interpretations}

\section{Why is a rise in C-efficiency particularly growth promoting?}

The above results indicate that raising the VAT through a rise in C-efficiency is more growth promoting than doing so through a rise in the standard rate. However, what could explain this result? To answer this, it is useful to recognize that the previous literature argues that a key source of distortions within the VAT system is the presence of exemptions (i.e., no tax is charged on sales, but the VAT charged on inputs is not refunded or credited), which, in

\footnotetext{
${ }^{34}$ The coefficient of 0.035 means that a one percent increase in C-efficiency, offset by a fall in the standard rate, promotes growth by 0.035 percentage points.

${ }^{35}$ Still, one (very) tentative way of considering the growth effect of this component is to regard the ratio of consumption to total taxes as a proxy of informal (underground) economy, and then to link informal economy and growth. For example, if informal economy is measured by "revenue not reported to, and not discovered by, the tax authorities produced in underground activities (Tanzi, 1999, page F344)", since it indicates that the government receives less revenue than it should, a rise in this ratio may correspond to a lager informal economy. However, as Tanzi (1999) clarifies, this is not the only possible measure of informal economy, and in general, the definition of an informal economy is quite controversial itself (see e.g., Schneider, 2005). Thus, the growth interpretation based on the economy's degree of informality (cf. Elgin and Birinci, 2016), even if attempted, is bound to be highly debatable.
} 
turn, narrows the VAT base, and lowers C-efficiency. As Crawford et al. (2010) emphasize, the fundamental reason why exemptions are distortionary is that by breaking the chain of output tax and input credit, they create an element of production taxation. For example, they illustrate that to the extent that VAT exempted sectors face different input prices across countries, exemptions can distort competition. ${ }^{36}$ Further, exemptions may give businesses an incentive to self-supply (to avoid production taxation entailed in input prices), hampering the contracting out of certain goods and services and possibly reducing the efficiency of their operation.

Indeed, these distortions from exemptions might reduce long-run growth through different channels. For example, Cnossen (2010) point out that the fact that exemptions are common in healthcare and education sectors increases the cost for firms wishing to conduct research through hospitals and universities, as exempted sectors cannot take credit for the VAT paid on their inputs. The increased cost, in turn, could discourage firms' research activities, eventually dampening growth through lower total factor productivity (TFP). Further, because firms in exempted sectors are unable to recover the VAT on their spending including that on capital goods, firms' physical investment may be discouraged, lowering capital accumulation and thus growth. However, how important are these distortions to growth? Although it is not easy to be specific about the quantitative relevance of the effects, unrecoverable VAT liabilities from intermediate inputs purchased by sectors producing exempted supplies appears substantial in practice. For example, according to EC (2012), in 2011 in EU-27 countries unrecoverable VAT liabilities from intermediate inputs purchased by sectors producing exempted supplies accounted for $19 \%$ of all VAT liabilities (defined as the total amount of the VAT households and non-households are supposed to pay for, given their expenditure and the respective VAT rates). Also, they calculate that unrecoverable VAT on gross fixed capital formation expenditure of exempted sectors accounts for an additional $17 \%$ of total VAT liabilities, suggesting a nontrivial adverse effect through slower capital accumulation.

Also, rate differentiation itself, which is caused both by reduced rates and exemptions, may have a negative macroeconomic impact. First, the presence of multiple

\footnotetext{
${ }^{36}$ Since financial sectors are often exempted, the distorting effects can be cascading further into the costs of businesses using financial services.
} 
VAT rates generates well-cited increased administration costs (e.g., Ebrill et al, 2001).

Second, and potentially more fundamental, rate differentiation distorts consumer choices by affecting the relative prices of goods and services. Admittedly, however, their macroeconomic influence is rather speculative. In particular, regarding relative price distortions, while they are often shown to reduce consumers' welfare (e.g., Mirrlees et al., 2011), it is not clear how and to what extent they may adversely affect economic growth in the long run. Still, given that the use of VAT rate differentiation is widely spread in advanced economies, administrative costs and relative price distortions may also have also a nontrivial long-run impact. ${ }^{37}$

Overall, the above result that a rise in C-efficiency is particularly growth promoting can be interpreted as follows. In advanced economies, trends in C-efficiency are primarily driven by changes in policy choices related to rate differentiation and exemptions, rather than changes in compliance (Keen, 2013 and Ueda, 2017). This suggests that for those economies base broadening measures of removing reduced rates and exemptions are key driving forces of a rise in C-efficiency in the long run. ${ }^{38}$ Then, such base-broadening measures, roughly corresponding to a rise in C-efficiency in OECD countries, mitigate various distortions, including the ones associated with production taxation, and thus help promote growth in the long run. In the meantime, notice that a rise in the VAT through the standard rate forgoes all the mentioned efficiency gains.

\section{Assessing the channels of transmission}

In relation to the above interpretation, Table 4 examines the possibility that a rise in C-efficiency might promote growth through different channels. In particular, it presents results of an alternative regression framework where, unlike Table 3, the investment ratio is not controlled for. That is, while regressions thus far assumed implicitly that C-efficiency

\footnotetext{
${ }^{37}$ To gauge the extent of rate differentiation, it is useful to the "effective" VAT rate calculated by EC (2012). As they point out, this rate, obtained as VAT liabilities divided by the total expenditure, contains information on how much households and non-households really pay, after reduced (and zero) rate and exemptions are taken into account. They calculate that in 2011 in EU-27, the effective rate was 9 percent on average, while the average of standard rates was 20.7 percent. This large difference signifies the wide spread use of rate differentiation.

${ }^{38}$ Although not assessed in the paper, reductions in the compliance gap manifested in C-efficiency increases can also have growth-promoting effects through channels of transmission akin to those discussed here. This may occur since VAT non-compliant sectors de facto experience a form of VAT exemption like that of legallyexempted activities.
} 
and other components of the VAT affect growth mainly through TFP (by controlling for the investment ratio and employment growth), Table 4 assumes that the VAT can affect growth through capital accumulation as well. Columns 1 to 3 repeat the estimation of Table 3 (Columns 2-4, where the VAT components are added), but without including the investment ratio. In Column 2, the growth effect of an increase in the VAT, offset by a fall in total income taxes, is still highly significant when this is driven by a rise in C-efficiency. Notice that the coefficient on the VAT share in Column 2 (0.23) is larger than the corresponding figure in Column 3 of Table 3 (0.19), and the coefficient on C-efficiency in Column 1 is also larger (0.046) than the one in Column 2 of Table 3 (0.035). These observations, as conjectured above, suggest that C-efficiency promotes growth also through the investment channel. Columns 4 to 6 also omit employment growth (as well as investment). The key results on C-efficiency remain essentially unchanged.

Table 4: Allowing for different channels of transmission

\begin{tabular}{|c|c|c|c|c|c|c|}
\hline \multirow{3}{*}{$\begin{array}{l}\text { Estimation method } \\
\text { Financing taxes } \\
\end{array}$} & \multicolumn{6}{|c|}{ PMG } \\
\hline & \multicolumn{6}{|c|}{ Total income } \\
\hline & $(1)$ & $(2)$ & (3) & $(4)$ & $(5)$ & (6) \\
\hline \multicolumn{7}{|c|}{ Dependent variable: real GDP per capita growth } \\
\hline Total taxes/GDP & $\begin{array}{c}-0.0527 \\
(-1.29)\end{array}$ & $\begin{array}{c}-0.0287 \\
(-0.68)\end{array}$ & $\begin{array}{c}-0.0345 \\
(-0.95)\end{array}$ & $\begin{array}{c}-0.159 * * * \\
(-3.18)\end{array}$ & $\begin{array}{c}-0.110 * * \\
(-2.13)\end{array}$ & $\begin{array}{c}-0.0985 * * \\
(-2.03)\end{array}$ \\
\hline VAT/Total taxes & $\begin{array}{c}-0.0406 \\
(-1.31)\end{array}$ & $\begin{array}{c}0.227 * * * \\
(6.54)\end{array}$ & $\begin{array}{l}\text { 0.126* } \\
(1.85)\end{array}$ & $\begin{array}{c}-0.0918 * * \\
(-2.16)\end{array}$ & $\begin{array}{c}0.217 * * * \\
(4.86)\end{array}$ & $\begin{array}{c}\mathbf{0 . 0 2 7 4} \\
(0.30)\end{array}$ \\
\hline $\begin{array}{l}\text { Other taxes/ } \\
\text { Total taxes }\end{array}$ & $\begin{array}{l}0.0247 \\
(1.26)\end{array}$ & $\begin{array}{c}0.0394 * * \\
(2.03)\end{array}$ & $\begin{array}{l}0.0250 \\
(1.24)\end{array}$ & $\begin{array}{c}-0.00795 \\
(-0.33)\end{array}$ & $\begin{array}{c}0.00727 \\
(0.30)\end{array}$ & $\begin{array}{l}-0.0185 \\
(-0.72)\end{array}$ \\
\hline C-efficiency & $\begin{array}{l}0.0461 * * * \\
(6.56)\end{array}$ & & $\begin{array}{c}0.0184^{*} \\
(1.73)\end{array}$ & $\begin{array}{l}0.0495 * * * \\
(5.60)\end{array}$ & & $\begin{array}{c}0.0332 * * \\
(2.38)\end{array}$ \\
\hline Standard rate & & $\begin{array}{c}-0.0338 * * * \\
(-6.21)\end{array}$ & $\begin{array}{c}-0.0289 * * * \\
(-2.86)\end{array}$ & & $\begin{array}{c}-0.0378 * * * \\
(-5.71)\end{array}$ & $\begin{array}{c}-0.0201 \\
(-1.57)\end{array}$ \\
\hline $\begin{array}{l}\text { Consumption } \\
\text { ratio }\end{array}$ & $\begin{array}{c}0.0249 * \\
(1.86)\end{array}$ & $\begin{array}{c}-0.00916 \\
(-0.75)\end{array}$ & & $\begin{array}{c}0.000461 \\
(0.03)\end{array}$ & $\begin{array}{c}-0.0324 * * \\
(-2.22)\end{array}$ & \\
\hline $\begin{array}{l}\text { Employment } \\
\text { growth }\end{array}$ & $\begin{array}{c}0.507 * * * \\
(13.03) \\
\end{array}$ & $\begin{array}{c}0.502 * * * \\
(12.93)\end{array}$ & $\begin{array}{c}0.531 * * * \\
(14.27)\end{array}$ & & & \\
\hline EC coefficient $(\phi)$ & $\begin{array}{c}-0.917 * * * \\
(-17.10)\end{array}$ & $\begin{array}{c}-0.917 * * * \\
(-16.85)\end{array}$ & $\begin{array}{c}-0.930 * * * \\
(-17.25)\end{array}$ & $\begin{array}{c}-0.792 * * * \\
(-18.60)\end{array}$ & $\begin{array}{c}-0.796 * * * \\
(-18.76)\end{array}$ & $\begin{array}{c}-0.794 * * * \\
(-18.99)\end{array}$ \\
\hline Crisis & $\begin{array}{c}-0.0159^{* * *} \\
(-6.48)\end{array}$ & $\begin{array}{c}-0.0167 * * * \\
(-6.76)\end{array}$ & $\begin{array}{c}-0.0155^{* * *} \\
(-6.13)\end{array}$ & $\begin{array}{c}-0.0141 * * * \\
(-6.12)\end{array}$ & $\begin{array}{c}-0.0146^{* * * *} \\
(-6.54)\end{array}$ & $\begin{array}{c}-0.0130 * * * \\
(-5.70)\end{array}$ \\
\hline Countries & 30 & 30 & 30 & 30 & 30 & 30 \\
\hline Observations & 944 & 944 & 944 & 944 & 944 & 944 \\
\hline
\end{tabular}

Notes: see notes to Table 3. 


\section{RoBUSTNESS}

This section conducts robustness checks for the key results of Tables 2 and 3. First, we explain the nature of the robustness tests. We then provide concise descriptions of the key results.

\section{A. Robustness tests}

Excluding the 2008-16 period. First, we estimate regressions after excluding the 20082016 period (inclusive). This allows us to check whether results are robust even when the recent period after the global financial crisis, during which GDP growth rates in advanced economies were systematically low, is excluded from the sample. In particular, this test addresses the concern that the relatively weak effect of the VAT standard rate on growth is driven by a simultaneous rise in the VAT standard rate across OECD countries during the post-

crisis period (Figure 1), when the average GDP growth rate was low. We ensure that there are (at least) 20 successive annual observations per country, which means that the number of countries in the sample shrinks inevitably by considering this shorter sample.

Controlling for lagged GDP per capita. Second, we include the log of lagged per capita real GDP as an independent variable. ${ }^{39}$ The aim is to control for possible convergence effects that may affect our long-run estimations. Specifically, we modify Eq. (1) as:

$$
g_{i, t}=\sum_{k=0}^{1} \boldsymbol{f}_{i, t-k}^{\prime} \delta_{k i}+\sum_{k=0}^{1} \sum_{j=1}^{n} \delta_{k i, j}^{Z} z_{i, j, t-k}+\lambda_{i} g_{i, t-1}+\mu_{i} y_{i, t-1}+\zeta_{i} \operatorname{crisis}_{i, t}+\epsilon_{i, t},
$$

where the difference is the addition of the log of real GDP per capita in period $t-1, y_{i, t-1}$. The presence of convergence effects corresponds to a negative value for the parameter $\mu_{i}$, namely that countries which are relatively richer are expected to grow at a slower pace.

\footnotetext{
${ }^{39}$ For instance, Gemmell et al. (2014), who conduct PMG/MG estimations using annual data for 15 OECD countries, control for lagged per capita GDP routinely in their investigation of the growth effects of tax rates.
} 
Using an ARDL model with 2 lags. Third, we consider an ARDL model with two lags both for growth rates and tax variables, instead of one as done above. (Lagged GDP per capita is not added here.) That is, Eq. (1) is modified as:

$$
g_{i, t}=\sum_{k=0}^{2} \boldsymbol{f}_{i, t-k}^{\prime} \delta_{k i}+\sum_{k=0}^{2} \sum_{j=1}^{n} \delta_{k i, j}^{Z} z_{i, j, t-k}+\sum_{l=1}^{2} \lambda_{l i} g_{i, t-l}+\zeta_{i} \text { crisis }_{i, t}+\epsilon_{i, t}
$$

Because the number of independent variables is high particularly when considering the growth effects of VAT components, we mitigate a degrees of freedom problem by ensuring that there are at least 30 successive observations available for each country. Accordingly, the number of countries included in the sub-sample falls. We restrict the regression equation to include a maximum of 2 lags, since the available time series is not very long.

Considering reverse causality problems. Fourth, and perhaps most important, we address possible endogeneity concerns. Specifically, various papers on taxation and growth discuss the possible reverse causality from growth to taxes, which may affect the estimated coefficients on the VAT obtained here. For instance, Figure 2 shows that within our sample C-efficiency (considering a deviation from the national average over the sample period) and the output gap are positively correlated. ${ }^{40}$ This is a well-known feature of C-efficiency reported in the literature (e.g., Ueda, 2017). Further, we confirm that the composition of total taxation, particularly the share of income taxes, is also cyclical (see Appendix C). These observations prompt us to consider the potential reverse causality from growth to taxes, despite the caveat that since our main interest is the long-run growth effect of the VAT, it is unclear to what extent the cyclicality of taxes may affect our long-run estimates.

\footnotetext{
${ }^{40}$ Output gap is calculated as log difference between real GDP and its trend (obtained using the HodrickPrescott filter).
} 
Figure 2: C-efficiency and output gap

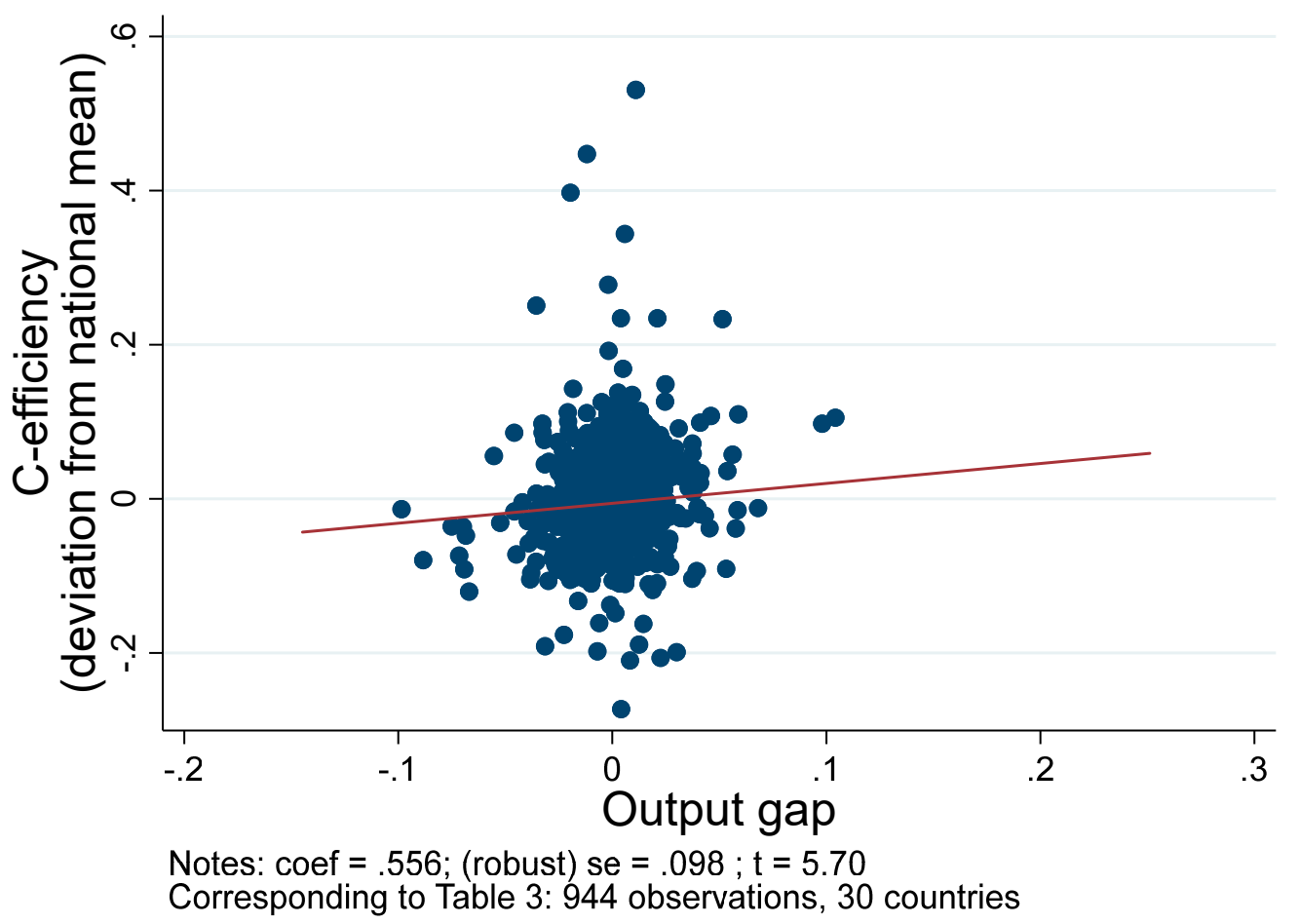

Specifically, following Bleaney et al. (2001) and Gemmell et al. (2011), we disallow the contemporaneous relation between fiscal variables and growth by imposing $\delta_{0 i}=0$ in Eq. (1). The estimation equation thus becomes:

$$
g_{i, t}=\boldsymbol{f}_{i, t-1}^{\prime} \delta_{1 i}+\sum_{k=0}^{1} \sum_{j=1}^{n} \delta_{k i, j}^{Z} z_{i, j, t-k}+\lambda_{i} g_{i, t-1}+\zeta_{i} \operatorname{crisis}_{i, t}+\epsilon_{i, t}
$$

In Eq. (11), unless the causal effect of the expectation of future growth rates causes a change in current-period tax variables, the estimated long-run coefficient on tax variables should be free from the reverse causality problem. ${ }^{41}$

\section{B. Test results}

Tables 5 and 6 present summary results for all the robustness tests. Columns 1 to 3 of each table correspond to Columns 2 to 4 of Table 2 about the growth effects of reallocations towards the VAT, where the financing tax element is total income, personal, and corporate

\footnotetext{
${ }^{41}$ Following Bleaney et al. (2001) and Gemmell et al. (2011), our estimation also omits the contemporaneous correlation between investment rate and growth, i.e., $\delta_{0 i}^{Z}=0$ for investment.
} 
income taxes, respectively. Columns 4 to 6 correspond to Columns 2 to 4 of Table 3 about the effects of the different VAT components, where the compensating element is always total income taxes. All the results shown below are based on the PMG method. ${ }^{42}$

Table 5 presents the estimation results of the tests: 1) excluding the post-crisis period (upper sub-table); and 2) controlling for lagged GDP per capita (lower sub-table). In relation to Table 2 above, the result that the VAT is generally more growth promoting than total income taxes remains unaffected (Column 1, in both sub-tables). Disaggregating income taxes, however, we observe that personal income taxes, rather than corporate income taxes, appear to be more distortionary, unlike Table 2 (Columns 2 and 3). Turning to the assessment of the results in Table 3, both robustness tests indicate that an increase in the VAT through C-efficiency, offset by a fall in (total) income taxes, is indeed growth promoting (Column 5). However, if the VAT is raised through other components, i.e., both the standard rate and the consumption ratio (Columns 4 and 6), the reallocation from income taxes does not foster growth, reinforcing the relevance of the design of VAT revenue increases in affecting growth. Further, the VAT-revenue neutral increase in C-efficiency, offset by a fall in the standard rate, is confirmed to promote growth (Columns 4 and 5). To note, in the lower subtable, the coefficient on lagged real GDP per capita is significantly negative, suggesting convergence effects.

\footnotetext{
${ }^{42}$ We tested the equality of long-run coefficients (i.e., conducted the Hausman test) for all the models considered below, and confirmed that the use of the PMG method is always supported.
} 
Table 5: Robustness (1): omitting the post-crisis period and adding initial GDP per capita

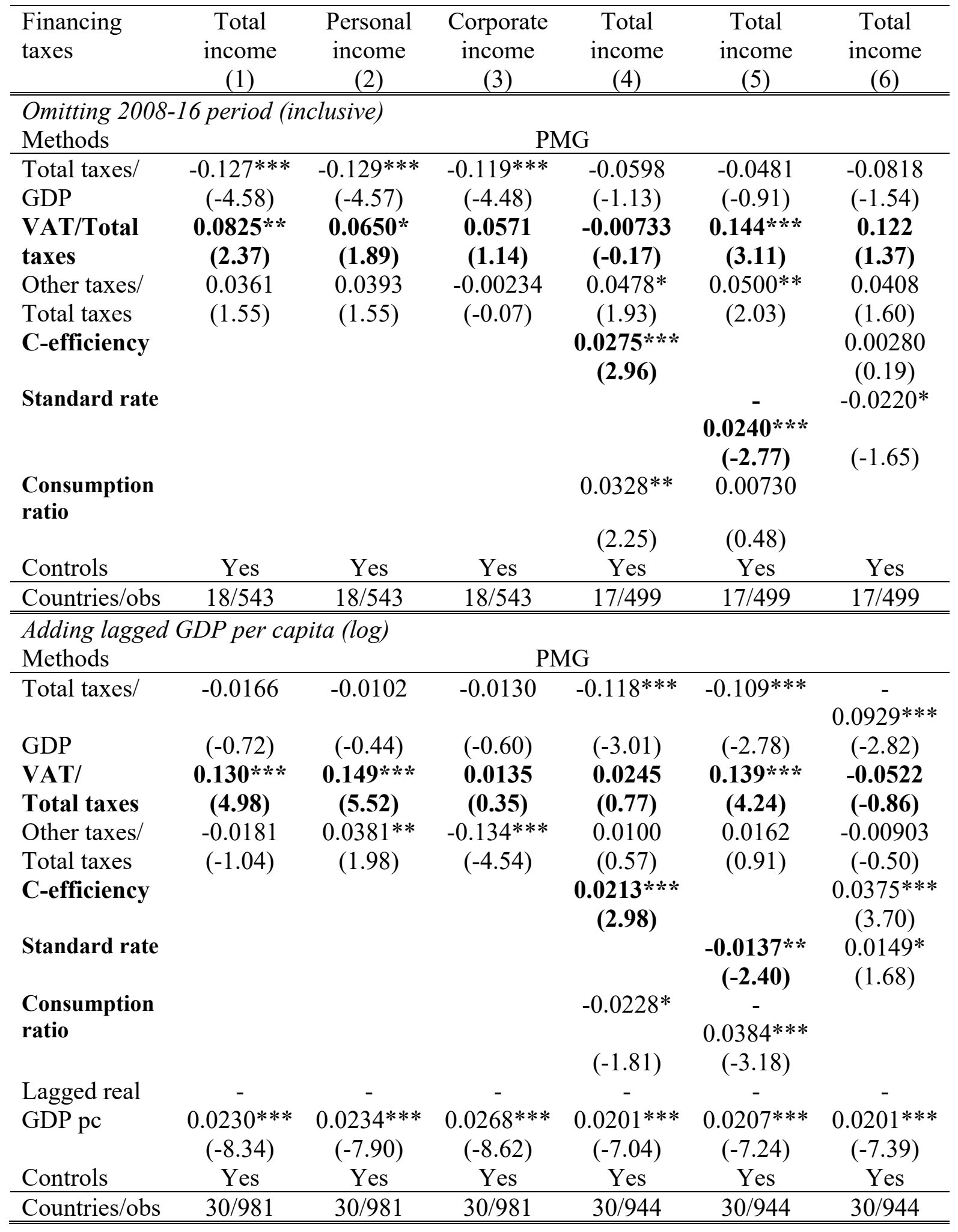

Notes: Dependent variable: real GDP per capita growth. In both upper and lower parts, ARDL model with 1 lag is estimated. Controls include investment rate and employment growth. EC coefficient, short-run coefficients and crisis dummy (in the case of the lower part) are not shown for brevity. See notes to Tables 2 and 3. 
Table 6 summarizes the results of the tests: 1) using an ARDL model with 2 lags (upper sub-table); and 2) omitting the contemporaneous relation between tax variables and growth (lower sub-table). Columns 1 to 3 generally show that the VAT is more growth friendly than income taxes. Columns 4 to 6 confirm that for both robustness tests an increase in VAT revenue through C-efficiency is growth promoting. Column 4 in the upper sub-table shows that a rise in the VAT, even when driven by a rise in the standard rate, fosters growth (albeit significance is only at 10\%). However, the coefficient (0.08) is notably smaller than that of Column 5 (0.26), and the significant effect of the standard rate is not observed in other robustness checks. Likewise, Column 6 in the lower sub-table indicates that a rise in the VAT through the consumption ratio increases growth. However, this is not a robust result, since in different specifications this effect vanishes. Last, Columns 5 and 6 in both sub-tables show that for a given level of VAT revenue a rise in C-efficiency, offset by a fall in the standard rate, fosters growth. Overall, we conclude that the main results from Table 2 and 3 are largely robust. 
Table 6: Robustness (2): using ARDL with 2 lags and omitting contemporaneous relation

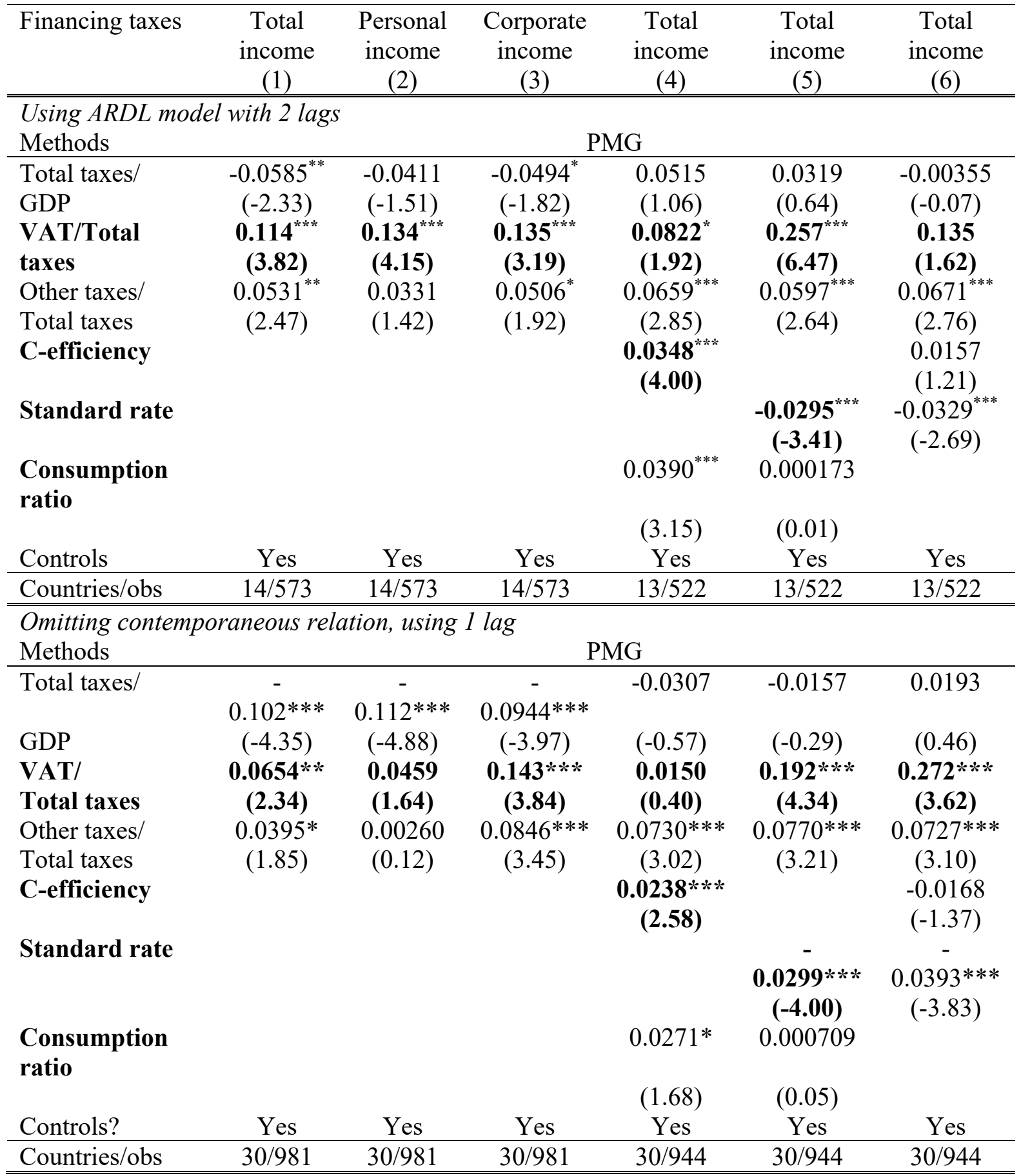

Notes: Dependent variable: real GDP per capita growth. Controls include investment rate and employment growth. EC coefficient, short run coefficients and crisis dummy are not shown for brevity. See notes to Tables 2 and 3. 


\section{CONCLUDING REMARKS}

This paper investigated how the growth effect of the VAT may differ depending on whether it is raised through C-efficiency or the standard rate. We showed that an increase in VAT revenue, financed by a fall in income taxes, promotes growth only when this happens through a rise in C-efficiency, but not when this occurs through a rise in the standard rate. Further, a rise in C-efficiency, offset by a fall in the standard rate, also fosters growth, indicating that the former is significantly more growth friendly than the latter. Given that in advanced economies a rise in C-efficiency is approximated well by the broadening of the VAT base through fewer reduced rates and exemptions, we interpreted the growth-promoting effect of $\mathrm{C}$-efficiency as likely arising from a reduction of various distortions associated with a narrow tax base, particularly the ones created by exemptions.

This paper contributes to the literature by highlighting the relevance of tax design on growth, a relation which has been largely ignored in the previous related works, regardless of the type of taxes. However, there are two main caveats to acknowledge. First, it is important to notice that there is a limitation to the VAT decomposition method used here. Specifically, as Keen (2013) emphasizes, it does not capture the behavioral responses of taxpayers to policy changes. For example, our exercise is silent on possible changes in taxpayers' compliance behavior induced by a change in the VAT standard rate. This is a methodological limitation, although the problem may not be necessarily severe in our context of OECD countries, because as Keen (2013) and Ueda (2017) point out, compliance issues do not appear to be that significant in explaining the behavior of C-efficiency in advanced economies. Second, as noted in the paper and in various other places including OECD (2008), it is important to acknowledge the existence of conceptual issues surrounding the interpretation of C-efficiency. In particular, increases in C-efficiency can result from policy measures that may erode the quality of the VAT and thus may not lead to efficiency gains, such as introducing exemptions for intermediate goods and/or denying VAT refunds to exporters. These caveats thus suggest that a careful interpretation of our results is needed from a policy perspective.

We conclude by suggesting one extension to the current analysis. Although this paper highlighted the relevance of VAT design in the context of long-run growth, growth is clearly not the only aspect a government is concerned about. In particular, it would be useful to examine the possible role of VAT design in affecting income inequality. While some works 
already explore the possible welfare effects of a broadening of the VAT base across different income groups (e.g., Mirrlees et al., 2011, EC, 2012), there still appears to be a gap in the literature to assess empirically the effects on income distribution. For example, applying a similar macro-panel approach used in this paper to evaluate VAT design effects on inequality might be a fruitful exercise.

\section{APPENDIX}

\section{A. Data sources}

The growth rate of annual real GDP per capita is calculated using real GDP per capita from the Penn World Tables (PWT 9.0, Feenstra et al., 2015). Since PWT 9.0 covers until 2014, for 2015 and 2016 we calculate the growth rate figure using real GDP per capita from IMF's World Economic Outlook (WEO). Tax revenue data, including VAT revenue at the general government level, are from the OECD Revenue Statistics Database. A VAT standard rates dataset, which requires information on the month in which the rate was changed, is assembled using various sources, including the OECD, European Commission, IMF's Tax Policy Reform Database (Amaglobeli et al., 2018), the Inter-American Center of Tax Administrations (CIAT) (for Chile), and various official country documents. Final consumption (before VAT revenue is excluded), required to calculate C-efficiency and the consumption ratio, is obtained from WEO. The control variables of investment rate and employment growth are also from WEO. The lagged per capita real GDP, controlled for in robustness tests, is also from PWT 9.0.

\section{B. Unit root tests}

As indicated in the main text, we undertook two different panel unit root tests that allow for testing within unbalanced panels: the Maddala and Wu (1999) test and the Im et al. (2003) test. As shown in Table B1, below, both tests confirm that the null of non-stationarity is rejected at the $1 \%$ level for all variables (except for the VAT standard rate, which cannot be tested through the Im et al. (2003) test). 
Table 7: Panel unit root tests

\begin{tabular}{lll}
\hline \multirow{2}{*}{ Variable } & \multicolumn{2}{c}{ H0: panel contains unit roots } \\
\cline { 2 - 3 } & Maddala and Wu (1999) & Im et al. $(2003)$ \\
\hline \hline GDP p. c. growth rate & $\chi(60): 306.60$ & t-bar: -14.44 \\
& p-value: 0.00 & p-value: 0.00 \\
\hline Investment rate & $\chi(60): 106.60$ & t-bar: -4.00 \\
& p-value: 0.00 & p-value: 0.00 \\
\hline Employment growth & $\chi(60): 272.73$ & t-bar: -12.45 \\
& p-value: 0.00 & p-value: 0.00 \\
\hline Total taxes / GDP & $\chi(60): 132.96$ & t-bar: -3.86 \\
& p-value: 0.00 & p-value: 0.00 \\
\hline VAT / Total taxes & $\chi(60): 116.22$ & t-bar: -3.34 \\
& p-value: 0.00 & p-value: 0.00 \\
\hline Total taxes-VAT-Inc taxes) / Total taxes & $\chi(60): 104.91$ & t-bar: -6.68 \\
& p-value: 0.00 & p-value: 0.00 \\
\hline C-efficiency (log) & $\chi(60): 117.73$ & t-bar: -5.49 \\
& p-value: 0.00 & p-value: 0.00 \\
\hline VAT standard rate (log) & $\chi(60): 92.21$ & -- \\
\hline Consumption / Total taxes (log) & p-value: 0.00 & -- \\
\hline
\end{tabular}

Note: 944 observations, 30 countries. For the Maddala and $\mathrm{Wu}$ (1999) test, the number of lags used is specified as 1. For the Im et al. (2003) test, the lags included are based on the Akaike's Information Criterion.

\section{Cyclicality of tax compositions}

Figure $\mathrm{C} 1$ presents the correlation between the tax shares in total taxes (considering deviations from the national means) and the output gap. While the VAT share does not show a statistically-significant cyclical pattern, the income tax share does show it. 
Figure 3: Correlation between tax shares and output gap
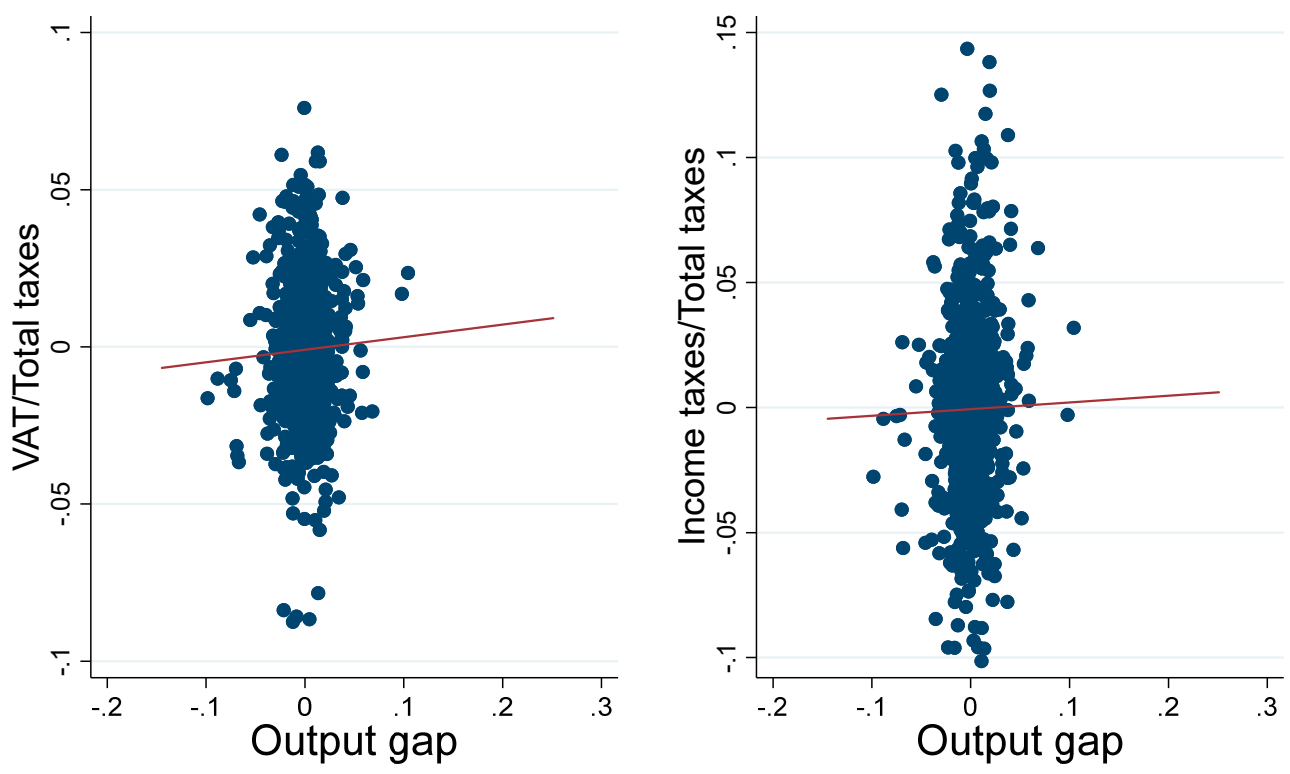

Notes: VAT: coef $=.022 ;$ (robust) $\mathrm{se}=.0365 ; \mathrm{t}=0.60$

Income taxes: coef $=.219$; (robust) $\mathrm{se}=.043 ; \mathrm{t}=5.08$

Both tax shares are deviations from respective national means

944 observations, 30 countries 


\section{REFERENCES}

Acosta-Ormaechea, S. S. Sola and J. Yoo, 2018, "Tax Composition and Growth: A Broad Cross-country Perspective", German Economic Review, https://doi.org/10.1111/geer.12156.

Aizenman, J., and Y. Jinjarak, 2008, "The Collection Efficiency of the Value Added Tax: Theory and International Evidence," Journal of International Trade \& Economic Development, Vol. 17, No. 3, pp. 391-410.

Alm J., and A. El-Ganainy, 2013, "Value-added taxation and consumption," International Tax and Public Finance, 20:1, pp. 105-128.

Amaglobeli, D., V. Crispolti, E. Dabla-Norris, P. Karnane, and F. Misch, 2018, "Tax Policy Measures in Advanced and Emerging Economies: A Novel Database" IMF Working Paper $18 / 110$

Arnold, J.M., Brys, B, Heady C., Johansson, Å., Schwellnus, C. and Vartia L., 2011, “Tax Policy for Economic Recovery and Growth.” Economic Journal, 121, pp. F59-F80.

Bleaney, M., Gemmell, N., and Kneller, R., 2001, “Testing the endogenous growth model: Public expenditure, taxation, and growth over the long run." Canadian Journal of Economics, 34, 36-57.

Crawford, I., Keen, M., and Smith, S., 2010, "Value Added Taxes and Excises", pp. 275-362 in James Mirrlees and others (eds), Dimensions of Tax Design: The Mirrlees Review, Oxford: Oxford University Press for Institute for Fiscal Studies

Cnossen, S., 2010, "Value Added Taxes and Excises: Commentary", pp. 370-386 in James Mirrlees and others (eds), Dimensions of Tax Design: The Mirrlees Review, Oxford: Oxford University Press for Institute for Fiscal Studies

Dabla-Norris, E., and F., Lima, 2018, "Macroeconomic Effects of Tax Changes: Evidence from Fiscal Consolidations," IMF Working Paper 18/220.

De Mello, Luiz, 2009, “Avoiding the Value-added Tax: Theory and Cross-country Evidence,"

Public Finance Review, Vol. 37, No. 1, pp. 27-46.

Ebrill, L., M., Keen, J-P Bodin, and V. Summers, 2001, The Modern VAT. International Monetary Fund, Washington DC.

Elgin, C., and S. Birnici, 2016, "Growth and Informality: A Comprehensive Panel Data Analysis," Journal of Applied Economics, XIX:2, pp. 271-292. 
European Commission (EC), 2011, "A retrospective evaluation of elements of the EU VAT system," Unpublished.

http://ec.europa.eu/taxation_customs/resources/documents/common/publications/studies/repo $\underline{\text { rt evaluation vat.pdf }}$

European Commission (EC), 2012, “A study on the economic effects of the current VAT rates structure," Unpublished.

https://ec.europa.eu/taxation customs/sites/taxation/files/docs/body/vat rates structure final report.pdf

Feenstra, R.C., R. Inklaar, and M.P. Timmer, 2015, "The Next Generation of the Penn World Table" American Economic Review, 105:10, pp. 3150-3182

Gemmell, N., Kneller, R., and Sanz, I., 2011, "The timing and persistence of fiscal policy impacts on growth: Evidence from OECD countries." Economic Journal, 121, F33-F58

Gemmell, N., Kneller, R., and Sanz, I., 2014, "The growth effects of tax rates in the OECD." Canadian Journal of Economics, 47, 1217-1255

Gemmell, N., Kneller, R., and Sanz, I., 2016, "Does the composition of government expenditure matter for long-run growth levels?" Oxford Bulletin of Economics and Statistics, $78,522-547$

Im, K. S., Pesaran, M. H., and Shin, Y., 2003, “Testing for unit roots in heterogeneous panels", Journal of Econometrics, 115:1, pp. 53-74

IMF, 2011, "Revenue mobilization in developing countries," Policy Paper Series, International Monetary Fund, Washington, D.C.

Kneller, R., Bleaney, M., and Gemmell, N., 1999, "Fiscal policy and growth: evidence from OECD countries." Journal of Public Economics, 74, 171-190

Kneller, R., and Misch, F., 2011, "What Does Ex-post Evidence Tell us About the Output Effects

of Future Tax Reforms?” ZEW Discussion Papers, No. 11-029.

Keen, M., 2013, “The Anatomy of the VAT.” National Tax Journal, Vol. 66, pp. 423-446.

Maddala, G. S., and Wu, S., 1999, “A Comparative Study of Unit Root Tests with Panel Data and a New Simple Test", Oxford Bulletin of Economics and Statistics, 61:0, pp. 631-52

Mirrlees, J., Adam, S., Besley, T., Blundell, R., Bond, S., Chote, R., Gammie, M., Johnson, P., Myles, G. and Poterba, J., 2011, Tax by Design: The Mirrlees Review, Oxford: Oxford University Press for Institute for Fiscal Studies

Morozumi, A. and Veiga, F.J., 2016, "Public spending and growth: The role of government accountability” European Economic Review 89, pp. 148-171 
OECD, 2008, "Consumption Tax Trends 2008, VAT/GST and Excise Rates, Trends and Administration Issues”, OECD Publishing, Paris, https://doi.org/10.1787/ctt-2008-en.

OECD, 2018, “Consumption Tax Trends 2018, Trends and Policy Issues”, OECD Publishing, Paris, https://doi.org/10.1787/ctt-2018-en.

Pesaran, M.H., Y. Shin, and R.P. Smith, 1999, "Pooled mean group estimation of dynamic heterogeneous panels" Journal of the American Statistical Association 94:446, pp. 621-634

Pesaran, M.H., and R.P. Smith, 1995, "Estimating long-run relationships from dynamic heterogeneous panels" Journal of Econometrics 68, pp. 79-113

Riera-Crichton, D., C. Vegh and G. Vuletin, 2016, "Tax multipliers: Pitfalls in measurement and identification," Journal of Monetary Economics, 79, pp. 30-48.

Sancak, C., J. Xing and R. Velloso, 2010, "Tax Revenue Response to the Business Cycles," IMF Working Paper 10/71.

Schneider, F, 2005, "Shadow economies around the world: what do we really know?" European Journal of Political Economy, 21, pp. 598-642.

Summers, L.H., 2014, "U.S. Economic Prospects: Secular Stagnation, Hysteresis, and the Zero Lower Bound” Business Economics, 49:2.

Tanzi, V, 1999, "Uses and Abuses of Estimates of the Underground Economy," Economic Journal, 109, pp. F338-F347.

Tanzi, V., and H.R. Davoodi, 2000, “Corruption, Growth, and Public Finances," IMF Working Paper 00/182.

Ueda, J., 2017, "The evolution of potential VAT revenues and C-efficiency in advanced economies" IMF Working Paper 17/158.

Xing, J., 2012, “Tax structure and growth: How robust is the empirical evidence?" Economics Letters, 117:1, pp. 379-382. 